\title{
The Epigenetic Effects of a High Prenatal Folate Intake in Male Mouse Fetuses Exposed In Utero to Arsenic
}

\author{
Verne Tsang $^{a}$, Rebecca C. Fry ${ }^{b}$, Mihai D. Niculescuc, Julia E. Rager ${ }^{b}$, Jesse Saunders ${ }^{a}$, \\ David S. Paul ${ }^{a}$, Steven H. Zeisel ${ }^{a, c}$, Michael P. Waalkes ${ }^{d}$, Miroslav Stýblo ${ }^{a}$, and Zuzana \\ Drobnáa, ${ }^{*}$ \\ aDepartment of Nutrition, University of North Carolina at Chapel Hill, Chapel Hill, North Carolina \\ 27599, USA \\ ${ }^{b}$ Department of Environmental Sciences and Engineering, University of North Carolina at Chapel \\ Hill, Chapel Hill, North Carolina 27599, USA \\ CUNC Nutrition Research Institute, Department of Nutrition, University of North Carolina at Chapel \\ Hill, Chapel Hill, North Carolina 27599, USA \\ dNIEHS, Research Triangle Park, North Carolina 27709, USA
}

\section{Abstract}

Inorganic arsenic (iAs) is a complete transplacental carcinogen in mice. Previous studies have demonstrated that in utero exposure to iAs promotes cancer in adult mouse offspring, possibly acting through epigenetic mechanisms. Humans and rodents enzymatically convert iAs to its methylated metabolites. This reaction requires S-adenosylmethionine (SAM) as methyl group donor. SAM is also required for DNA methylation. Supplementation with folate, a major dietary source of methyl groups for SAM synthesis, has been shown to modify iAs metabolism and the adverse effects of iAs exposure. However, effects of gestational folate supplementation on iAs metabolism and fetal DNA methylation have never been thoroughly examined. In the present study, pregnant CD1 mice were fed control (i.e. normal folate, or $2.2 \mathrm{mg} / \mathrm{kg}$ ) or high folate diet $(11 \mathrm{mg} / \mathrm{kg}$ ) from gestational day (GD) 5 to 18 and drank water with 0 or $85 \mathrm{ppm}$ of As (as arsenite) from GD8 to 18 . The exposure to iAs significantly decreased body weight of GD18 fetuses and increased both SAM and S-adenosylhomocysteine (SAH) concentrations in fetal livers. High folate intake lowered the burden of total arsenic in maternal livers but did not prevent the effects of iAs exposure on fetal weight or hepatic SAM and SAH concentrations. In fact, combined folate-iAs exposure caused further significant body weight reduction. Notably, iAs exposure alone had little effect on DNA methylation in fetal livers. In contrast, the combined folate-iAs exposure changed the $\mathrm{CpG}$ island methylation in 2,931 genes, including genes known to be imprinted. Most of these genes were associated with neurodevelopment, cancer, cell cycle, and signaling networks. The canonical Wnt-signaling pathway, which regulates fetal development, was among the most affected biological pathways. Taken together, our results suggest that a

(C) 2012 Elsevier Inc. All rights reserved.

*Corresponding author: Zuzana Drobna, PhD, Department of Nutrition, 2003 Michael Hooker Research Center, CB\# 7461, University of North Carolina at Chapel Hill, Chapel Hill, NC 27599-7461, Phone: (919) 843-2719, Fax: (919) 843-0776,

drobnazu@med.unc.edu.

Conflict of interest

The authors declare that there are no conflicts of interest.

Publisher's Disclaimer: This is a PDF file of an unedited manuscript that has been accepted for publication. As a service to our customers we are providing this early version of the manuscript. The manuscript will undergo copyediting, typesetting, and review of the resulting proof before it is published in its final citable form. Please note that during the production process errors may be discovered which could affect the content, and all legal disclaimers that apply to the journal pertain. 
combined in utero exposure to iAs and a high folate intake may adversely influence DNA methylation profiles and weight of fetuses, compromising fetal development and possibly increasing the risk for early-onset of disease in offspring.

\section{Keywords}

Arsenic; folate; epigenetics; DNA methylation; transplacental exposure; CD1 mice

\section{Introduction}

Inorganic arsenic (iAs) is a common, naturally occurring drinking water contaminant (Smith et al., 2000; Focazio et al., 2000). Millions of people around the world are exposed to iAs in drinking water at levels that exceed the World Health Organization (WHO) recommended limit of $10 \mu \mathrm{g}$ of arsenic/L (10 ppb) (WHO, 2011). Chronic exposures to iAs are associated with increased prevalence of skin cancer and cancers of internal organs (e.g., liver, bladder, lung) (IARC 2004) and non-cancerous diseases such as diabetes, cardiovascular and neurological disease (Navas-Acien, 2008; 2005; Del Razo, 2011; States, 2009; Gong, 2012; Rosado, 2007; Tsai, 2003). The adverse health outcomes associated with iAs exposure are determined in part by gender (Vahter, 2007), ethnicity (Vahter, 1995), level of exposure (Gong, 2012; Valenzuela, 2009; Hopenhayn-Rich, 1998), and length of exposure (Ehrenstein, 2005; Fernandez, 2012).

Population and laboratory studies indicate that early life exposure to iAs, including intrauterine exposure, is associated with an increased risk of adverse health effects later in life (Vahter, 2008; Waalkes, 2007; Tokar, 2012). Increased liver cancer mortality, associated with in utero and/or early-life exposures to iAs, has been reported in Chile (Liaw, 1998). A dose-related increase in hepatic and adrenal cancer in adult male offspring, and urogenital cancer in adult female offspring of $\mathrm{C} 3 \mathrm{H}$ and $\mathrm{CD} 1$ mice prenatally exposed to arsenite (iAs ${ }^{\mathrm{III}}$ ), has been reported by Waalkes and associates (Waalkes, 2003, 2006a,b). Further studies suggested that iAs acts as an endocrine disruptor (Shen, 2007) and/or affects DNA methylation profiles in offspring (Liu, 2007). Thus, epigenetic mechanisms involving the modulation of DNA methylation may underline the adverse effects of gestational exposure to iAs.

It was shown that iAs methylation efficiency increases during the first trimester of pregnancy (Gardner, 2010) and iAs and its metabolites readily cross the placenta and enter the fetus (Concha, 1998; Rudge, 2009; Devesa, 2006; Jin, 2006). The biomethylation of iAs is catalyzed by arsenic ( +3 oxidation state) methyltransferase (AS3MT) that requires Sadenosylmethionine (SAM) as methyl group donor, and endogenous reductants as cofactors (Lin, 2002; Waters, 2004; Ding, ms accepted; Drobna, 2005; Drobna, 2006). In humans and rodents, iAs is metabolized to monomethyl-, dimethyl-, and trimethyl-arsenic metabolites (MAs, DMAs, and TMAs) that contain either trivalent $\left(\mathrm{As}^{\mathrm{III}}\right)$ or pentavalent $\left(\mathrm{As}^{\mathrm{V}}\right)$ arsenic (Challenger, 1945; Hayakawa, 2005). The liver is considered to be the most important site for iAs biotransformation (Geubel, 1988; Buchet, 1984). The majority of the ingested iAs and of its metabolites are excreted via urine (Fujisawa, 2007). In vitro and in vivo studies have demonstrated that trivalent arsenicals are more toxic and reactive than their pentavalent forms (Styblo, 2002; Drobna, 2005; Kitchin, 2008), and have longer half-life in tissues due to their high-affinity for thiol groups (Hughes, 2008). Recent population studies showed association between the presence of urinary trivalent methylated arsenic metabolites (MAs ${ }^{\text {III }}$ and DMAs ${ }^{\mathrm{III}}$ ), and higher risk of premalignant skin lesions (Valenzuela, 2005) and increased prevalence of diabetes (Del Razo, 2011) in individuals chronically exposed to iAs in drinking water. The variations in urinary arsenical profiles of subjects exposed to iAs 
have been linked to genetic polymorphism in AS3MT (Agusa, 2011). However, other factors such as age (Kurttio, 1998), sex (Lindberg, 2008), pregnancy (Hopenhayn, 2003a), nutrition (Heck, 2007), and environmental exposures (Concha, 1998) were shown to influence the metabolism of arsenic as well.

Suboptimal intake of nutrients that are essential for SAM synthesis, including methionine, choline, folate, and vitamin B12, or the knockout of the folate receptor, have been shown to impair iAs methylation and to increase susceptibility of laboratory animals to toxic and carcinogenic effects of iAs exposure (Heck, 2007; Wlodarzczyk, 2001; Nelson, 2007). Folate, a dietary precursor required for SAM synthesis, has been shown to modulate the capacity to methylate iAs and the risk of diseases in individuals exposed to iAs in drinking water. Plasma folate levels were found to be positively associated with the percentage of urinary arsenic represented by DMAs, and negatively with the percentage represented by MAs and iAs (Gamble, 2005). In addition, supplementation with folate enhanced iAs methylation as indicated by an increase in the percentage of DMAs in urine (Gamble, 2006). A similar increase in DMAs percentage found in urine of pregnant women is thought to be associated with pregnancy rather than with plasma folate status (Gardner, 2011). Increased iAs methylation during pregnancy was shown to be only marginally affected by nutritional folate status $(\mathrm{Li}, 2008)$.

The periconceptional folic acid supplementation has been widely used to reduce the incidence of congenital malformation and the risk of having premature or low birth weight babies (Greenberg, 2011). The role of folic acid in one-carbon metabolism, as a participant to the transfer of methyl groups, is considered to be critical for the development of placenta and fetus, and for the epigenetic programming of fetal DNA (Zeisel, 2009). Thus, the requirement for SAM in fetal development and in iAs detoxification may play a critical role in determining the birth outcomes and the epigenetic onset of adult disease. Effects of in utero exposure to iAs on gene-specific and genome-wide DNA methylation profiles in liver of mouse fetuses have never been examined. In our study we used an established transplacental model for iAs carcinogenesis (Waalkes, 2003) to evaluate the effects of prenatal exposure to iAs on DNA and iAs methylation, and on one-carbon metabolism. We also examined whether effects of iAs exposure in fetal livers can be modified by high folate intake. Our data show that high folate intake does not prevent the low fetal body weights associated with iAs exposure. In fact, it results in large changes in the DNA methylation of genes involved in neurodevelopment and cell cycle, which may influence fetal and postnatal development.

\section{Material and Methods}

\subsection{Materials}

Sodium meta-arsenite (iAs $s^{\mathrm{III}}$, 99\% purity) was purchased from Sigma-Aldrich. An iAs ${ }^{\mathrm{III}}$ solution at the final concentration of $85 \mathrm{ppm}$ of arsenic (As) provided to animals for drinking was prepared in deionized water every three days to minimize oxidation of iAs ${ }^{\mathrm{III}}$ to pentavalent arsenate $\left(\mathrm{iAs}^{\mathrm{V}}\right.$ ). Arsenic is classified by the International Agency for Research on Cancer as a human carcinogen. Therefore, necessary precautions are required during handling to avoid exposure.

\subsection{Animals, diet, and treatment}

This study was approved by the UNC Institutional Animal Care and Use Committee (IACUC). Primipregnant CD1 mice were purchased from Charles River Laboratories (Wilmington, MA) at gestation day 1 (GD1) and housed in the University of North Carolina at Chapel Hill (UNC-CH) Animal Facility, which is fully accredited by the American Association for Accreditation of Laboratory Animal Care. The pregnant mice were housed 
individually in a climate-controlled environment with a $12 \mathrm{~h}$ light/dark cycle at $20-22^{\circ} \mathrm{C}$ and $50 \%$ relative humidity, and with unrestricted access to diet and water. Mice were fed a control semi-purified AIN-76A diet (Dyets Inc., Bethlehem, PA) with $2.2 \mathrm{mg} / \mathrm{kg}$ of folate (CT diet) or the same diet with $11 \mathrm{mg} / \mathrm{kg}$ of folate (FS diet). The level of folate in CT diet has been shown to provide an adequate folate intake for rodents. Specifically, previous studies showed that levels of folate in the liver, erythrocytes, and serum of mice fed a chow containing $2 \mathrm{mg} / \mathrm{kg}$ of folate (Bills, 1992) resemble those found in humans with a normal folate status (Hoppner and Lampi, 1980; Pietrzik, 2007; Rader, 2002). The relatively high level of folate in the FS diet $(11 \mathrm{mg} / \mathrm{kg})$ has been used to test genetic mouse models for neural tube defects for responsiveness to prenatal folate supplementation (Gray, 2009). This level is five-fold higher than the adequate level for rodents and thus, it is consistent with the upper level folate intakes of 5- to 10-times of the recommended dietary allowance (400 $\mu \mathrm{g} /$ day) which has been used in human interventional trials (Malinow, 1997; Lin, 2004). Both $\mathrm{CT}$ and FS diets contained $1.1 \mathrm{~g} / \mathrm{kg}$ of choline chloride and $1 \%$ of succinyl sulfathiazole, an inhibitor of folate production by gut bacteria. Animals drank either deionized water or water containing $85 \mathrm{ppm}$ of As as iAs III. This concentration of iAs ${ }^{\mathrm{III}}$ causes liver tumors in the male offspring exposed in utero via drinking water (Waalkes, 2003). Pregnant mice (12 mice/group) were randomly assigned to the following treatment groups: CT group, mice receiving CT diet from GD1 to 18 and deionized water from GD1 to 18; CT/iAs group, mice receiving CT diet from GD1 to 18 and deionized water containing $85 \mathrm{ppm}$ of As from GD8 to 18; FS group, mice receiving FS diet from GD5 to 18 and deionized water from GD1 to 18; and FS/iAs group, mice receiving FS diet from GD5 to 18 and deionized water containing $85 \mathrm{ppm}$ of As from GD8 to 18. Mice were monitored daily for signs of toxicity and discomfort. Water and food consumption, and body weight were monitored over the entire period of exposure. At GD18 venous blood from dams and liver tissues from dams and fetuses were collected. Tails from fetuses were collected and the DNA was isolated after Proteinase K (Qiagen) digestion, and phenol:chloroform:isopropyl alcohol (25:24:1, v/v; Invitrogen) extraction was used for sex determination as described by Lambert et al. (2000). Only livers collected from male fetuses were used in this study.

\subsection{Analysis of arsenic species in liver and plasma samples}

Arsenic species in maternal and fetal livers and in blood plasma were determined by hydride generation-cryotrapping-atomic absorption spectrometry (HG-CT-AAS) (Hernández-Zavala, 2008; Currier, 2011). Briefly, 10\% (w/v) liver homogenates prepared in deionized water were microwave digested in ultrapure phosphoric acid (J.T. Baker, Phillipsburg NJ) overnight. Aliquots of the digestates (50 $\mu \mathrm{l}$ each) were reduced with $2 \%$ cysteine (EMD Chemicals Inc., Gibbstown, NJ), and analyzed for As species. Aliquots of blood plasma (50 $\mu l$ each) were analyzed directly without digestion. The concentrations of total iAs (iAs ${ }^{\mathrm{III}}+$ $\mathrm{iAs}^{\mathrm{V}}$ ), total MAs (MAs ${ }^{\mathrm{III}}+\mathrm{MAs}^{\mathrm{V}}$ ), and total DMAs $\left(\mathrm{DMAs}^{\mathrm{III}}+\mathrm{DMAs}^{\mathrm{V}}\right.$ ) were calculated using calibration curves prepared for standard $\mathrm{iAs}^{\mathrm{V}}, \mathrm{MAs}^{\mathrm{V}}, \mathrm{DMAs}^{\mathrm{V}}(0.5-2.0 \mathrm{ppb})$ reduced with $2 \%$ cysteine.

\subsection{Folate analysis}

A microbiological assay based on the growth response of $L$. casei to folic acid (Tamura, 1990) was used to determine folate levels in maternal plasma, using services provided by the Nutrition and Obesity Research Center (NORC) at UNC-Chapel Hill, NC. The plasma folate levels were determined based on a calibration curve prepared by using a 5-

methyltetrahydrofolic acid (Sigma) as standard, within a concentration range of 10-200 pg.

\subsection{S-adenosylmethionine and S-adenosylhomocysteine analysis}

Levels of S-adenosylmethionine (SAM) and S-adenosylhomocysteine (SAH) were determined by NORC using high-performance liquid chromatography (HPLC) as described 
by She et al. (1994). This method provides a rapid resolution of both SAM and SAH in a single run by direct injection of the perchloric acid extract of tissue allowing reduction of procedural and analytical errors in determination of SAM/SAH ratio. SAM and SAH purchased from Sigma were used to prepare standard solutions and to generate calibration curves.

\subsection{DNA-methylation analysis}

High-molecular-weight (20-150 kb) genomic DNA (gDNA) was isolated from fetal livers after digestion with Proteinase K (Qiagen) using phenol:chloroform extraction followed by isoamylalcohol precipitation. Isolated DNA was processed for microarray hybridization as previously described (Yan, 2002). Briefly, two micrograms of gDNA were digested into small ( $\leq 200 \mathrm{bp}$ ) fragments with MseI restriction enzyme (New England Biolabs (NEB), Beverly, MA) that recognizes TTAA sites. The DNA fragments with cleaved ends purified by QIAquick PCR Purification Kit (Qiagen, Germantown, MD) were ligated to unphosphorylated linkers (H12: 5' ${ }^{\prime}$-TAATCCCTCGGA-3'; H24: 5'

AGGCAACTGTGCTATCCGAGGGAT-3') using Fast Link Ligase (Epicentre, Madison, WI), purified using QIAquick column (Qiagen) and vacuum-dried. The ligated DNA was first digested with methylation-sensitive endonuclease BstUI (NEB) followed by second digestion with methylation-sensitive endonuclease HpaII (NEB). The linker polymerase chain reaction using H24 primer and Deep Vent ${ }^{\left(\mathrm{exo}^{-}\right)}$DNA polymerase (NEB) was then used to amplify all methylated fragments of ligated DNA. PCR products were purified using QIAquick column (Qiagen), vacuum-dried and shipped to the University Health Network Microarray Centre (Toronto, Canada; http://www.microarrays.ca). Here, DNA samples were labeled with fluorescence dyes (Cy3, Cy5) and hybridized to mouse 16k CpG-island microarrays (Agilent). Each treatment group was hybridized against universal control (genomic DNA isolated from the mouse liver) purchased from Biochain (Hayward, CA). Arrays were washed then scanned using an Agilent G2565BA scanner, and quantified using ArrayVision v. 8.0 (Imaging Research Inc.).

\subsection{Quantitative PCR}

Quantitative Real-Time PCR (qPCR) was used to examine the expression levels of genes involved in iAs and one-carbon metabolism, DNA methylation, and of selected genes with altered $\mathrm{CpG}$ island methylation. Mouse gene specific Taqman Gene Expression Assays and Gene Assay Mix (Applied Biosystems) were used. qPCR was carried out on a Roche LightCycler 480 system. The expression level of Gapdh transcript was used as an endogenous reference for quantification. The fold-change in gene expression was calculated using Comparative $\mathrm{C}_{\mathrm{t}}$ Method ( $\Delta \Delta \mathrm{C}_{\mathrm{t}}$ method) described elsewhere (Livak, 2001).

\subsection{Statistical analysis}

The data collected from folate analysis, As speciation analysis, SAM and SAH analysis, and quantitative PCR analysis were evaluated using Origin 7.5 software. Effects of diet and iAs exposure, as well as interactions between diet and iAs exposure, were analyzed by analysis of covariance. Differences between the treatment groups were evaluated by analyses of variance (ANOVAs) with Bonferroni multiple-comparison post-hoc test. Values are expressed as Mean \pm S.E. for each treatment group $(n=7-11)$. The data with $\mathrm{p}<0.05$ were considered to be statistically significant.

Data generated by microarrays were pre-processed using Lowess normalization on a $\log [2]$ scale. The normalized data were analyzed by Principal Component Analysis and the Significance Analysis of Microarrays (Tusher, 2001), using the TM4 software Suite 4.6 (Saeed, 2003). Gene lists were corrected for a false discovery rate (FDR) threshold of 5\%. Network analysis was carried out using Ingenuity Software as described in recent studies 
(Fry, 2007; Smeester, 2011). Fisher's exact test was used to calculate a p-value determining the probability that the number of genes, whose DNA methylation was changed, within each molecular network and biological function, is due to chance alone.

\section{Results}

\subsection{Monitoring of animals}

Maternal water and food consumption were monitored between GD8 to 18 and recorded every three days until sacrifice. Dams exposed to $85 \mathrm{ppm}$ of As in drinking water drank $\sim 50 \%$ less water than mice in CT and FS groups (Fig. 1A). This observation is consistent with our previous studies, showing that the lower water intake does not affect the hydration status of the mice (Paul 2007, 2011). Based on the average water consumption between GD8 and GD18, mice in CT/iAs and FS/iAs groups ingested a total of $4.4 \mathrm{mg}$ and $3.5 \mathrm{mg}$ of As over the entire study period (i.e., $440 \mu \mathrm{g}$ and $350 \mu \mathrm{g}$ As per day), respectively. Similarly, mice receiving iAs ${ }^{\mathrm{III}}$ in drinking water consumed significantly less $(\sim 15-20 \%)$ food than mice drinking pure deionized water. However, there were no significant differences between the treatment groups when the food consumption by dams was normalized for number of fetuses. On average each dam consumed $\sim 4 \mathrm{~g}$ of chow/fetus during the period of GD8GD18 (Fig. 1B). To make sure that the dietary folate was efficiently absorbed we measured folate concentration in blood plasma. Mice fed the FS diet $(11 \mathrm{mg}$ folate $/ \mathrm{kg})$ had $>5$-times higher plasma folate concentrations than did mice fed the CT diet ( $2.2 \mathrm{mg}$ folate/kg).

Mice exposed to iAs ${ }^{\mathrm{III}}$ were monitored daily for signs of toxicity and discomfort. Most mice tolerated the exposure to $85 \mathrm{ppm}$ As without obvious problems. Two dams in FS/iAs group appeared lethargic with signs of vaginal bleeding noted at sacrifice. These mice ate and drank similar amounts of food and water as did other mice in this treatment group. Each of these two dams carried 15 fetuses. Fetuses dissected from these two dams were underdeveloped considering the stage of pregnancy (GD18). Therefore, these fetuses were not included in further analyses. Necropsies of other dams found no fetal abnormalities or macroscopic lesions. On average, each of these dams carried $12.2 \pm 2.3$ fetuses, including $6.6 \pm 2.4$ male and $5.6 \pm 2.8$ female fetuses. The location of fetuses in uterine horn and fetal body weights were recorded during dissection; placenta and internal organs of the dams were also examined. On average, male fetuses in all treatment groups were heavier by 5-7\% than female fetuses. However, the body weights of fetuses in CT/iAs group were $\sim 15 \%$ lower as compared to CT and FS groups. High folate intake was associated with further decrease in fetal weight in FS/iAs group ( 25\% lower than CT group; Fig. 1D). This decrease was significantly different from all other treatment groups.

\subsection{Maternal and fetal arsenical profiles}

The concentrations of iAs metabolites in maternal and male fetal livers were determined by HG-CT-AAS. We found that the average concentrations of total speciated As (i.e., sum of iAs + MAs + DMAs) in fetal livers in the treatment groups exposed to iAs were 5-6 times lower as compared to livers of dams (Fig. 2A, B). In addition, the composition of As species in maternal and fetal livers differed. DMAs was the major As species detected in both maternal and fetal livers, and represented approximately $40 \%$ and $60 \%$ of total As in livers of dams from CT/iAs and FS/iAs groups, respectively, and $\sim 80 \%$ in fetal livers from both groups. High folate intake significantly decreased the amount of iAs (Fig. 2A), and increased the methylation ratios of DMAs/MAs and (MAs+DMAs)/iAs in maternal livers (Table 1). No significant differences in the total or speciated As were observed in fetal livers from CT/iAs and FS/iAs groups (Fig. 2B). We also analyzed iAs metabolites in blood plasma collected from dams. Notably, DMAs accounted for 91.2 and $92 \%$ of total As in 
plasma of CT/iAs and FS/iAs dams while MAs represented only 6.1 and 4.4\%, respectively (Fig. 2C).

\subsection{SAM and SAH levels in fetal livers; one-carbon metabolism}

We analyzed the concentrations of SAM and S-adenosylhomocysteine (SAH) in fetal livers and calculated the transmethylation potential (i.e., SAM/SAH ratio). The average hepatic SAM concentrations were higher in CT/iAs, FS, and FS/iAs groups as compared to CT group (Fig. 3A). However, only the difference between CT and CT/iAs groups was statistically significant at $\mathrm{p}<0.05$. The hepatic $\mathrm{SAH}$ concentrations were also higher in all treatment groups as compared to CT group, with statistically significant differences found only for fetuses in CT/iAs and FS/iAs (Fig. 3B). The transmethylation potential represented by SAM/SAH ratio was lower in all treatment groups as compared to CT fetuses, but these differences were not significantly altered (Fig. 3C).

In addition to SAM and SAH concentrations, we analyzed mRNA levels for two enzymes involved in one-carbon metabolism, specifically, methionine adenosyltransferase (Mat2a) involved in SAM synthesis and S-adenosylhomocysteine hydrolase (Ahcy) participating in SAH hydrolysis, a step that converts SAH to the adenosine and homocysteine (Hcy). Results of quantitative PCR suggested a moderate, but not statistically significant increase in Mat2a transcript as a result of iAs exposure and, particularly of high folate diet (Fig. 4A). Ahcy mRNA levels were lower in livers of fetuses exposed to iAs as compared to fetuses in CT and FS groups (Fig. 4B). However, these differences were not statistically significant. We also examined mRNA levels for other enzymes involved in Hcy metabolism; 5methyltetrahydrofolate-homocysteine methyltransferase reductase (Mtrr) and cystathionine $\beta$-synthase (Cbs). While the mRNA levels for Mtrr were not significantly different among the treatment groups, $C b s$ mRNA levels were higher in livers of FS fetuses as compared to other treatment groups (eFig. 1 in Supplemental Material). We further evaluated the expression of methyltransferases involved in the utilization of methyl groups for DNA and iAs methylation, including DNA (cytosine-5)-methyltransferase 1 (Dnmt1), DNA (cytosine-5)-methyltransferase 3-alpha (Dnmt3a), and arsenic (+3 oxidation state) methyltransferase $(A s 3 m t)$. There were no significant differences in Dnmt 1 mRNA levels among the treatment groups (data not shown). Dnmt3a mRNA level was significantly lower in fetal livers from FS/iAs group as compared to CT group (Fig. 4C). Dnmt3a mRNA level was also lower in CT/iAs fetuses, but this difference was not statistically significant. Evaluation of mRNA and protein levels for As3mt did not reveal any significant differences between treatment groups (data not shown).

\subsection{DNA methylation pattern in fetal livers}

CpG-island microarrays were used to assess effects of iAs exposure and high folate intake on genomic DNA methylation profiles in fetal livers. Significance Analysis of Microarrays with false discovery rate (FDR) threshold $<5 \%$ identified significantly hyper-methylated and hypo-methylated probes in FS and FS/iAs treatment groups. Compared to fetal livers from CT group, the exposure to iAs alone altered the $\mathrm{CpG}$-island methylation pattern of only four DNA probes while high folate diet alone affected CpG-island methylation in 253 probes. The most pronounced changes in DNA methylation pattern were found for the combined high folate intake and exposure to iAs with 5,357 CpG-island probes showing significantly altered methylation levels. The lists of significantly changed CpG-island probes generated from Significance Analysis of Microarrays were used to identify corresponding genes, molecular networks and biological pathways using Ingenuity software. There were 12 and 2,770 genes with uniquely altered methylation patterns in FS and FS/iAs group, respectively (Fig. 5). Changes in the methylation pattern of 161 genes were shared by both these groups. Among the 161 shared genes, 41 genes were associated with gene expression $(p=1.20 \times$ 
$\left.10^{-9}\right)$ and 36 genes with embryonic development $\left(\mathrm{p}=1.63 \times 10^{-7}\right)$. The gene expression and embryonic development networks were also among the most affected networks in fetal livers from FS/iAs group, considering all 2,931 genes with significantly altered methylation pattern, with p-values of $1.85 \times 10^{-99}$ and $1.40 \times 10^{-74}$, respectively. Combined exposure to iAs and folate also changed the methylation of genes associated with cancer and neurodevelopment molecular networks (eTable 1 in Supplemental Material, Fig. 6A,B). Notably, Wnt-signaling pathway was one of the most affected biological pathways in FS/iAs group (Table 2, Fig. 7). We identified 58 genes with significantly altered methylation status that are associated with the Wnt-signaling pathway (Wnt3, Fzd8, Fzd10, Dvl1, Dvl3, Axin2, $C t n n b 1)$ or regulate this pathway ( $C d k n 2 a$, Rara, $T g f-\beta)$. In addition, the combined high folate diet and exposure to iAs affected the methylation patterns of $\mathrm{CpG}$ islands present in differentially methylated regions (DMRs) of imprinted genes involved in the regulation of embryogenesis and neural development (Gnas, Nnat, and Kcnk9) and imprinted genes associated with cancer (Igf2r, Dlk1, Tssc4, Grb10, and Mest) (Table 3). CpGs were identified as being in DMRs by using WAMIDEX, a Web Atlas of Murine Genomic Imprinting and Differential Expression, King's College, London (https://

atlas.genetics.kcl.ac.uk/atlas.php) and referenced previously (Arnaud, 2010).

\section{Discussion}

In our study we used the mouse model for transplacental arsenic carcinogenesis established by of Dr. Waalkes' group $(2003,2006 \mathrm{~b})$. They showed that the adult male offspring of CD1 mice, prenatally exposed to iAs ( $85 \mathrm{ppm}$ As) in drinking water, developed hepatocellular carcinoma (HCC). In addition, they found elevated levels of transcript for estrogen receptor alpha (ER-a) and hypomethylation of its promoter in HCC (Waalkes, 2004). Adopting the CD1 mouse model, our study examined effects of in utero exposure to iAs on gene-specific methylation, using genome-wide DNA methylation profiling in male fetal livers, and the role of high folate intake in modulating these effects.

The results of our study suggest that gestational exposure to iAs causes $\sim 15 \%$ reduction in male fetal body weight at GD18. These results are in agreement with previous population studies from Chile (Hopenhayn, 2003b) and Taiwan (Yang, 2003) where lower birth weights of neonates after in utero exposure to iAs were observed. Periconceptional folate supplementation has been widely used to reduce the incidence of congenital malformations and to prevent premature or low birth weight babies. Folate supplementation is also thought to facilitate detoxification of iAs (Gamble, 2005; 2006; 2007; Hall, 2009). However, our data suggest that, at least in mice, a high gestational folate intake (5-times above the adequate folate level in rodent diet) does not prevent body weight loss caused by iAs exposure. In fact, the high folate intake exacerbates the loss of body weight in iAs-exposed fetuses.

Low birth weight babies $(<2,500 \mathrm{~g})$ are at a significant risk for perinatal mortality and morbidity, and for the development of a broad range of diseases later in life, including cancer (Spector, 2009), CVDs, obesity, diabetes (Barker, 2003), congenital abnormalities (Spector, 2008), and learning disabilities (Lorenz, 1998; Saigal, 2000; Resnick, 1999). The low birth weight percentile is etiologically heterogeneous and molecular determinants are not well known. Gestational exposure to environmental pollutants and nutrients plays a critical role in determining the birth outcomes (Kaur, 2010) and the epigenetic onset of adult disease (Perera, 2011). Recent studies show an altered expression of imprinted genes in placentas from growth restricted fetuses and from infants with low birth weight (McMinn, 2006; Apostolidou, 2007; Tabano, 2010). Thus, the fetal and postnatal development could be negatively affected by epigenetic changes during gestation and by dysregulation of the corresponding signaling and metabolic pathways. For example, the incidence of 
hepatoblastoma, a liver cancer, is strongly increased among children with very low birth weight (Tanimura, 1998; Reynolds, 2004; McLaughlin, 2006).

The methylation of iAs by rat As3mt or human AS3MT requires SAM as methyl group donor (Lin, 2002; Waters, 2004; Ding, ms submitted). While folate supplementation facilitates iAs methylation in adults and children (Gamble, 2006; Hall, 2009), increased iAs methylation during pregnancy was shown to be only marginally affected by nutritional folate status (Gardner, 2011; Li, 2008). Liver is considered the main organ for iAs methylation and the main site for folate storage and metabolism. In our study high folate intake affected the retention of iAs, MAs, and DMAs only in maternal liver. Specifically, folate significantly decreased the burden of iAs $(\mathrm{p}<0.002)$ and increased the amount of DMAs in maternal livers, providing evidence that high folate intake plays a role in iAs biotransformation. Higher levels of folate may increase the rate of the conversion of iAs to DMAs as indicated by the first (MAs/iAs) and the second (DMAs/MAs) methylation ratios. No such differences were observed in fetal livers. Notably, the profiles of methylated arsenicals in fetal livers (i.e., percentage of total As represented by MAs and DMAs) resembled MAs and DMAs profiles in maternal plasma, but not those in maternal liver. We detected the presence of As3mt transcript in fetal livers but the level of As3mt protein evaluated by immunoblot analysis was very low, suggesting low As3mt activity. Thus, it is possible that the methylated arsenicals in fetal livers were transferred from maternal blood across the placenta. In a population study from Bangladesh, Hall et al. (2007) reported strong associations between maternal and cord blood arsenic metabolites, which provided evidence that maternal-fetal transport of arsenic readily occurs and the fetus is exposed to a complete spectrum of iAs metabolites.

Maternal plasma folate and homocysteine levels and/or polymorphisms in folate metabolizing genes have been implicated in iAs metabolism and in susceptibility to iAs toxicity (Hall, 2007; Engstrom, 2007). In our study, in utero exposures to iAs and folate tended to increase SAM levels in fetal livers, as well as the expression of methionine adenosyltransferase (Mat2a), an enzyme directly involved in SAM synthesis. Induction of SAM synthesis in the groups exposed to iAs would be consistent with a compensatory response to iAs exposure that increases the demand for methyl groups. An increase in SAM level due to high folate diet should be expected as the folate is directly involved in SAM synthesis. However, a significant increase in SAH levels accompanied by a decrease in the transmethylation potential (SAM/SAH) in CT/iAs and FS/iAs groups indicated that the efficiency of transmethylation reactions may be impaired due to reduced cellular methylation capacity, and that high folate intake did not prevent these changes. Under physiological conditions, $\mathrm{SAH}$, a product of the transmethylation reactions and a potent inhibitor of DNA methyltransferases, is further metabolized by S-adenosylhomocysteine hydrolase (Ahcy) to homocysteine and adenosine. Lower levels of Ahcy transcript in the livers of CT/iAs and FS/iAs fetuses may explain the higher levels of hepatic SAH in these treatment groups as compared to controls.

Three DNA methyltransferase enzymes (DNMT1, DNMT3A, and DNMT3B) are involved in active DNA methylation. DNMT1 catalyzes predominantly the methylation of hemimethylated DNA, and thus is responsible for maintenance of DNA methylation pattern (Takeshita, 2011). Both DNMT3A and DMNT3B function in de novo DNA methylation (Sharma, 2011) and their expression is developmentally regulated. Most genomic targets can be methylated by both DNMT3A and DNMT3B. However, DNMT3A is specifically required for the methylation of imprinted genes in germ cells while DNMT3B methylates the centromeric minor satellite repeats $(\mathrm{Li}, 2007)$. In our study, the combined maternal exposure to iAs and high folate diet led to significant decrease in fetal Dnmt3a expression, accompanied with changes in the $\mathrm{CpG}$ island methylation pattern of imprinted genes 
associated with cancer or with the regulation of embryogenesis and development (Table 3).

DIk1 (Delta-like 1, paternally imprinted) is highly expressed in mouse embryos and placenta during development, and plays a role as a growth factor responsible for maintaining cell proliferation prior to differentiation (Yevtodiyenko, 2006). In our study, hypomethylation in DIk 1 was associated with marginally significant increase ( 1.6 fold change; $\mathrm{p}=0.07)$ in transcript level (eFig. 2). Upregulation of Dlk1 due to epigenetic events was also shown to contribute to human hepatocellular carcinoma (Huang, 2007). Insulin-like growth factor receptor (Igf2r) which is expressed only from maternal allele in mice is biallelically expressed in humans. Igf $2 r$ functions as a tumor suppressor, thus it is expected that incidence of cancers that results from its inactivation will be higher in mice than in humans. Neuronatin, (Nnat) is expressed only from paternal allele and is involved in the regulation of ion channels during brain development, in forming and maintaining the structure of the nervous system, and in pituitary development and maturation (Wijnholds, 1995; Aikawa, 2003). Hypermethylation of its promoter has been associated with pituitary adenoma (Revill, 2009) as well as with pediatric leukemogenesis (Kuerbitz, 2002). Taken together, one could speculate that aberrant DNA methylation patterns of imprinted genes might be responsible for the epigenetic onset of disease not only in $\mathrm{F} 1$ generation but also in next generations, if such changes would be also present in the primordial germ cells of F1, but further research is needed.

Previous studies have linked epigenetic or gene expression changes to skin lesions in subjects exposed to environmental iAs (Pilsner, 2009; Smeester, 2011) and suggested that folate deficiency, hyperhomocysteinemia, and low urinary creatinine are risk factors (Pilsner, 2009). Two studies have examined the link between prenatal arsenic exposure and DNA methylation pattern of $A l u, L I N E-1$ and LUMA, p16, and $p 53$ genes in paired maternal and umbilical cord leukocytes (Kile, 2012; Pilsner, 2012). A positive association has been found between higher levels of iAs exposure and DNA methylation in LINE-1 repeated elements, and to a lesser degree within the promoter region of the tumor suppressor gene $p 16$ (Kile, 2012). In contrast, our study found no significant effects of iAs exposure on genome-wide and gen-specific DNA methylation pattern in fetal livers. However, a wide spectrum of genes with differentially altered methylation pattern has been identified after intrauterine co-exposure of fetuses to iAs and a high level of dietary folate. Molecular network analysis identified a large number of genes associated with cancer and neurodevelopment. Further studies are needed to determine gene-specific methylation profile in the brain tissues of fetuses exposed to iAs and folate. It has already been shown that the prenatal and postnatal iAs exposure of Wistar rats caused significant changes in promoter methylation of the genes involved in neuronal plasticity in the cortex and hippocampus (Martinez, 2011). In addition, several studies examining the relationship between iAs exposure and neurodevelopment in children showed reduced intellectual function and decreased learning ability, attention, and memory (Wasserman, 2007; Rosado, 2007; Dakeishi, 2006). A range of behavioral and cognitive impairments in the offspring of C57BL6/J mice prenatally exposed to iAs has been recently reported (Markowski, 2012). These data demonstrate the need for further investigation of arsenic as neurotoxic agent and its interactions with nutrient(s).

The WNT-pathway is one of the evolutionary conserved signaling pathways that regulate the development of tissues and organs. Aberrant WNT-signaling has been linked to human diseases such as cancer (Behari, 2010; Whittaker, 2010), type II diabetes (Bordonaro, 2009), and neurological diseases (Hur, 2010). In our study, this pathway was one of the most affected biological pathways in livers of FS/iAs fetuses. A recent study showed that hypermethylation of WNT2 promoter downregulated its expression in placenta, and it was associated with reduced fetal growth and low birth weight (Ferreira, 2011). In addition, Crooked tail ( $C d)$ mice, a model for neural tube defects (NTDs) bearing the point mutation 
in $L r p 6$, a co-receptor for canonical Wnt signaling, can be rescued by high dietary folate level (10 ppm, i.e., $10 \mathrm{mg}$ of folate per $\mathrm{kg}$ of diet). However, prenatal high folate intake increased early lethality and NTDs in $\mathrm{Lrp}^{-/-}$embryos (Gray, 2010). Gene expression analysis in these embryos found that folate and methionine metabolism, Wnt signaling, mitochondrial function, and cytoskeletal regulation were among the significantly affected pathways. In vitro experiments indicated that both deficiency and excess of folate had deleterious impact on transcriptional activation by the canonical WNT signaling pathway in NIH3T3 fibroblasts. Thus, it is possible that the epigenetic alterations of the genes involved in WNT pathway regulation, observed in our study after combined iAs and folate exposures, alter the expression of genes that affect Wnt signaling, possibly compromising fetal development as demonstrated by low fetal body weights. For example, Mest, an imprinted gene, has been shown to play an important role in embryo development, and to inhibit WNT signaling through regulation of LRP6 glycosylation (Jung, 2011). In our study, hypomethylation of Mest was observed in both FS and FS/iAs groups (Table 3). Thus, it is possible that high folate intake may play a role in epigenetic regulation of LRP6 glycosylation and the presence of iAs in FS/iAs group may further pharmacologically compromise WNT signaling, for example via interference with the maturation and plasma membrane localization of LRP6.

In conclusion, this study is the first to indicate that in utero exposure of CD1 mice to iAs combined with high gestational folate intake results in low fetal weight at GD18, dramatic changes in global DNA methylation in fetal livers, and in aberrant $\mathrm{CpG}$ island methylation of genes associated with fetal development and cancer networks. Further studies will be needed to better understand implications of these findings for human populations chronically exposed to iAs from the environment, particularly for pregnant women who may potentially use high-dose folate supplements that are available over-the-counter to reduce the NTDs risk.

\section{Supplementary Material}

Refer to Web version on PubMed Central for supplementary material.

\section{Acknowledgments}

\footnotetext{
We acknowledge Laurie Bennie and Mrs. Felecia Walton for their assistance during the mice dissection. This work has been supported in part by National Institutes of Health Grant DK056350 to the University of North Carolina at Chapel Hill's Nutrition Obesity Research Center, by a grant from the National Institute of Environmental Health Sciences (P30ES010126), and by the American Institute for Cancer Research/World Cancer Research Fund (AICR/ WCRF) to ZD. This research was supported by the National Toxicology Program, National Institute of Environmental Health Sciences (NIEHS). This article may be the work product of an employee or a group of employees of the NIEHS, NIH, however, the statements contained herein do not necessarily represent the statements, opinions or conclusions of the NIEHS, NIH or the United States Government. The content of this publication does not necessarily reflect the views or the policies of the Department of Health and Human Services, nor does mention of trade names, commercial products, or organizations imply endorsement by the U.S. Government.
}

\section{References}

1. Aikawa S, Kato T, Elsaesser F, Kato Y. Molecular cloning of porcine neuronatin and analysis of its expression during pituitary ontogeny. Exp Clin Endocrin Diabetes. 2003; 111:475-479.

2. Agusa T, Fujihara J, Takeshita H, Iwata $H$. Individual variations in inorganic arsenic metabolism associated with AS3MT genetic polymorphisms. Int J Mol Sci. 2011; 12:2351-2382. [PubMed: 21731446]

3. Apostolidou S, Abu-Amero S, O’Donoghue K, Frost J, Olafsdottir O, Chavele KM, Whittaker JC, Loughna P, Stanier P, Moore GE. Elevated placental expression of the imprinted PHLDA2 gene is associated with low birth weight. J Mol Med. 2007; 85:379-387. [PubMed: 17180344] 
4. Barker DJP. The developmental origins of adult disease. Eur J Epidemiol. 2003; 18:733-736. [PubMed: 12974544]

5. Behari J. The Wnt/ $\beta$-catenin signaling pathway in liver biology and disease. Expert Rev Gastroenterol Hepatol. 2010; 4:745-756. [PubMed: 21108594]

6. Bills ND, Koury MJ, Clifford AJ, Dessypris EN. Ineffective hematopoiesis in folate-deficient mice. Blood. 1992; 79:2273-2280. [PubMed: 1571542]

7. Bordonaro M. Role of Wnt signaling in the development of type 2 diabetes. Vitam Horm. 2009; 80:563-581. [PubMed: 19251050]

8. Buchet JP, Geubel A, Pauwels S, Mahieu P, Lauwerys R. The influence of liver disease on the methylation of arsenite in humans. Arch Toxicol. 1984; 55:151-154. [PubMed: 6497648]

9. Challenger F. Biological methylation. Chem Rev. 1945; 36:315-361.

10. Concha G, Vogler G, Lezcano D, Nermell B, Vahter M. Exposure to inorganic arsenic metabolites during early human development. Toxicol Sci. 1998; 44:185-190. [PubMed: 9742656]

11. Concha G, Nermell B, Vahter MV. Metabolism of inorganic arsenic in children with chronic high arsenic exposure in Northern Argentina. Environ Health Perspect. 1998; 106:355-359. [PubMed: 9618352]

12. Currier JM, Svoboda M, Matousek T, Dedina J, Styblo M. Direct analysis and stability of methylated trivalent arsenic metabolites in cells and tissues. Metallomics. 2011; 3:1347-1354. [PubMed: 22015847]

13. Dakeishi M, Murata K, Grandjean P. Long-term consequences of arsenic poisoning during infancy due to contaminated milk powder. Environ Health. 2006; 31:31. [PubMed: 17076881]

14. Del Razo LM, Garcia-Vargas GG, Valenzuela OL, Castellanos EH, Sanchez-Pena LC, Currier JM, Drobna Z, Loomis D, Styblo M. Exposure to arsenic in drinking water is associated with increased prevalence of diabetes: a cross-sectional study in the Zimapan and Lagunera regions in Mexico. Environ Health. 2011; 10:73. [PubMed: 21864395]

15. Devesa V, Adair BM, Liu J, Waalkes MP, Diwan BA, Styblo M, Thomas DJ. Arsenicals in maternal and fetal mouse tissues after gestational exposure to arsenite. Toxicology. 2006; 224:147-155. [PubMed: 16753250]

16. Ding L, Saunders RJ, Drobna Z, Walton FS, Xun P, Thomas DJ, Styblo M. Methylation of arsenic by recombinant human wild-type arsenic ( +3 oxidation state) methyltransferase and its methionine 287 threonine (M287T) polymorh. Tox Appl Toxicol. (accepted).

17. Drobna Z, Waters SB, Devesa V, Harmon AW, Thomas DJ, Styblo M. Metabolism and toxicity of arsenic in human urothelial cells expressing rat arsenic ( +3 oxidation state)-methyltransferase. Toxicol Appl Pharmacol. 2005; 207:147-159. [PubMed: 16102566]

18. Drobna Z, Xing W, Thomas DJ, Styblo M. shRNA silencing of AS3MT expression minimizes arsenic methylation capacity of HepG2 cells. Chem Res Toxicol. 2006; 19:894-899. [PubMed: 16841956]

19. Engstrom S, Broberg K, Concha G, Nermell B, Warholm M, Vahter M. Genetic polymorphisms influencing arsenic metabolism: evidence from Argentina. Environ Health Perspect. 2007; 115:599-605. [PubMed: 17450230]

20. Fernandez MI, Lopez JF, Vivaldi B, Coz F. Long-term impact of arsenic in drinking water on bladder cancer health care and mortality rates 20 years after end of exposure. J Urology. 2012; 187:856-861.

21. Ferreira JC, Choufani S, Grafodatskaya D, Butcher DT, Zhao C, Chitayat D, Shuman C, Kingdom J, Keating S, Weksberg R. WNT2 promoter methylation in human placenta is associated with low birthweight percentile in the neonate. Epigenetics. 2011; 6:441-450.

22. Focazio MJ, Welch AH, Watkins SA, Helsel DR, Horn MA. A retrospective analysis on the occurrence of arsenic in ground-water resources of the United States and limitations on drinkingwater-supply characterizations. USGS, Reston, USA. 2000:1-21.

23. Fry RC, Navasumrit P, Valiathan C, Svensson JP, Hogan BJ, Luo M, Bhattacharya S, Kandjanapa K, Soontararuks S, Nookabkaew S, Mahidol C, Ruchirawat M, Samson LD. Activation of inflammation/NF-kappaB signaling in infants born to arsenic-exposed mothers. PLoS Genet. 2007; 3:e207. [PubMed: 18039032] 
24. Fujisawa S, Ohno R, Shigeno K, Sahara N, Nakamura S, Naito K, Kobayashi M, Shinjo K, Takeshita A, Suzuki Y, Hashimoto H, Kinoshita K, Shimoya M, Kaise T, Ohnishi K. Pharmacokinetics of arsenic species in Japanese patients with relapsed or refractory acute promyelocytic leukemia treated with arsenic trioxide. Cancer Chemother Pharmacol. 2006; 59:485-493. [PubMed: 16937107]

25. Gamble MV, Liu X, Ahsan H, Pilsner R, Ilievski V, Slavkovich V, Parvez F, Levy D, FactorLitvak P, Graziano JH. Folate, homocysteine, and arsenic metabolism in arsenic-exposed individuals in Bangladesh. Environ Health Perspect. 2005; 113:1683-1688. [PubMed: 16330347]

26. Gamble MV, Liu X, Ahsan H, Pilsner JR, Ilievski V, Slavkovich V, Parvez F, Chen Y, Levy D, Factor-Litvak P, Graziano JH. Folate and arsenic metabolism: a double-blind, placebo-controlled folic acid-supplementation trial in Bangladesh. Am J Clin Nutr. 2006; 84:1093-1101. [PubMed: 17093162]

27. Gamble MV, Liu XV, Slavkovich V, Pilsner JR, Ilievski, Factor-Litvak P, Levy D, Alam S, Islam M, Parvez F, Ahsan H, Graziano JH. Folic acid supplementation lowers blood arsenic. Am J Clin Nutr. 2007; 86:1202-1209. [PubMed: 17921403]

28. Gardner RM, Nermell B, Kippler M, Grander M, Li L, Ekstrom EC, Rahman A, Lonnerdal B, Hoque AM, Vahter M. Arsenic methylation efficiency increases during the first trimester of pregnancy independent of folate status. Reprod Toxicol. 2011; 31:210-218. [PubMed: 21078382]

29. Geubel AP, Mairlot MC, Buchet JP, Dive C, Lauwerys R. Abnormal methylation capacity in human liver cirrhosis. Int J Clin Pharmacol Res. 1988; 8:117-122. [PubMed: 3378853]

30. Gong G, O’Bryant SE. Low-level arsenic exposure, AS3MT gene polymorphism and cardiovascular diseases in rural Texas counties. Environ Res. 2012; 113:52-57. [PubMed: 22341486]

31. Gray JD, Ross ME. Mechanistic insights into folate supplementation from Crooked tail and other NTD-prone mutant mice. Birth Defects Res Clin Mol Teratol. 2009; 85:314-321.

32. Gray JD, Nakouzi G, Slowinska-Castaldo B, Dazard JE, Rao JS, Nadeau JH, Ross ME. Functional interactions between the LRP6 WNT co-receptor and folate supplementation. Hum Mol Genet. 2010; 19:4560-4572. [PubMed: 20843827]

33. Greenberg JA, Bell SJ, Guan Y, Yu YH. Folic acid supplementation and pregnancy: more than just neural tube defect prevention. Rev Obstet Gynecol. 2011; 4:52-59. [PubMed: 22102928]

34. Hall M, Gamble M, Slavkovich V, Liu X, Levy D, Cheng Z, van Green A, Yunus M, Rahman M, Pilsner R, Graziano J. Determinants of arsenic metabolism: blood arsenic metabolites, plasma folate, cobalamin, and homocysteine concentrations in maternal-newborn pairs. Environ Health Perpect. 2007; 115:1503-1509.

35. Hall MN, Liu X, Slavkovich V, Ilievski V, Pilsner JR, Alam S, Factor-Litvak P, Graziano JH, Gamble MV. Folate, cobalamin, cysteine, homocysteine, and arsenic metabolism among children in Bangladesh. Environ Health Perspect. 2009; 117:825-831. [PubMed: 19479028]

36. Hayakawa T, Kobayashi Y, Cui X, Hirano S. A new metabolic pathway of arsenite: arsenicglutathione complexes are substrates for human arsenic methyltransferase Cyt19. Arch Toxicol. 2005; 70:183-191. [PubMed: 15526190]

37. Heck JE, Gamble MV, Chen Y, Graziano JH, Slavkovich V, Parvez F, Baron JA, Howe GR, Ahsan H. Consumption of folate-related nutrients and metabolism of arsenic in Bangladesh. Am J Clin Nutr. 2007; 85:1367-1374. [PubMed: 17490975]

38. Hernandez-Zavala A, Matousek T, Drobna Z, Paul DS, Walton F, Adair BM, Dedina J, Thomas DJ, Styblo M. Speciation analysis of arsenic in biological matrices by automated hydride generation cryotrapping-atomic absorption spectrometry with multiple microflame quartz tube atomizer (multiatomizer). J Anal At Spectrom. 2008; 23:342-351. [PubMed: 18677417]

39. Hopenhayn C, Huang B, Christian J, Peralta C, Ferreccio C, Atallah R, Kalman D. Profile of urinary arsenic metabolites during pregnancy. Environ Health Perspect. 2003a; 111:1888-1891. [PubMed: 14644662]

40. Hopenhayn C, Ferreccio C, Browning SR, Huang B, Peralta C, Gibb H, Hertz-Picciotto I. Arsenic exposure from drinking water and birth weight. Epidemiology. 2003b; 14:593-602. [PubMed: 14501275] 
41. Hopenhayn-Rich C, Biggs ML, Smith AH. Lung and kidney cancer mortality associated with arsenic in drinking water in Cordoba, Argentina. Int J Epidemiol. 1998; 27:561-569. [PubMed: 9758107]

42. Hoppner K, Lampi B. Folate levels in human liver from autopsies in Canada. Am J Clin Nutr. 1980; 33:862-864. [PubMed: 7189090]

43. Huang J, Zhang X, Zhang M, Zhu JD, Zhang YL, Lin Y, Wang KS, Qi XF, Zhang Q, Liu GZ, Yu J, Cui Y, Yang PY, Wang ZQ, Han ZG. Up-regulation of DLK1 as an imprinted gene could contribute to human hepatocellular carcinoma. Carcinogenesis. 2007; 28:1094-1103. [PubMed: 17114643]

44. Hughes MF, Devesa V, Adair BM, Conklin SD, Creed JT, Styblo M, Kenyon EM, Thomas DJ. Tissue dosimetry, metabolism and excretion of pentavalent and trivalent dimethylated arsenic in mice after oral administration. Toxicol Appl Pharmacol. 2008; 227:26-35. [PubMed: 18036629]

45. Hur EM, Zhou FQ. GSK3 signaling in neuronal development. Nat Rev Neurosci. 2010; 11:539_ 551. [PubMed: 20648061]

46. IARC working group on the evaluation of carcinogenic risks to humans. Some drinking-water disinfectants and contaminants, including arsenic. IARC monographs on the evaluation of carcinogenic risks to humans/World Health Organization. International Agency for Research on Cancer. 2004; 84:1-477.

47. Jin Y, Xi S, Li X, Lu C, Li G, Xu Y, Qu C, Niu Y, Sun G. Arsenic speciation transported through the placenta from mother mice to their newborn pups. Environ Res. 2006; 101:349-355. [PubMed: 16458287]

48. Jung H, Lee SK, Jho EH. Mest/Peg1 inhibits Wnt signaling through regulation of LRP6 glycosylation. Biochem J. 2011; 436:263-269. [PubMed: 21375506]

49. Kaur P, Sachdeva R, Kochhar A. Impact of industrialization on nutritional and health status of pregnant women and their obstetric outcome. Ethno Med. 2010; 4:149-155.

50. Kile ML, Baccarelli A, Hoffman E, Tarantini L, Quamruzzaman Q, Rahman M, Mahiuddin G, Mostofa G, Hsueh YM, Wright RO, Christiani DC. Prenatal arsenic exposure and DNA methylation and umbilical cord blood leukocytes. Environ Health Perspect. 2012; 120:1061-1066. [PubMed: 22466225]

51. Kitchin KT, Wallace K. The role of protein binding of trivalent arsenicals in arsenic carcinogenesis and toxicity. J Inorg Biochem. 2008; 102:532-539. [PubMed: 18164070]

52. Kuerbitz SJ, Pahys J, Wilson A, Compitello N, Gray TA. Hypermethylation of the imprinted NNAT locus occurs frequently in pediatric acute leukemia. Carcinogenesis. 2002; 23:559-564. [PubMed: 11960906]

53. Kurttio P, Komulainen H, Hakala E, Kahelin H, Pekkanen J. Urinary excretion of arsenic after exposure to arsenic present in drinking water. Arch Environ Contam Toxicol. 1998; 34:297-305. [PubMed: 9504979]

54. Lambert JF, Benoit BO, Colvin GA, Carlson J, Delville Y, Quesenberry PJ. Quick sex determination of mouse fetuses. J Neurosci Methods. 2000; 95:127-132. [PubMed: 10752483]

55. Li L, Ekstrom EC, Goessler W, Lonnerdal B, Nermell B, Yunus M, Rahman A, El Arifeen S, Persson LA, Vahter M. Nutritional status has marginal influence on the metabolism of inorganic arsenic in pregnant Bangladeshi women. Environ Health Perspect. 2008; 116:315-321. [PubMed: 18335097]

56. Li JY, Pu MT, Hirasawa R, Li BZ, Huang YN, Zeng R, Jing NH, Chen T, Li E, Sasaki H, Xu GL. Synergistic function of DNA methyltransferases Dnmt3a and Dnmt3b in the methylation of Oct4 and Nanog. Mol Cel Biol. 2007; 27:8748-8759.

57. Liaw J, Marshall G, Yuan Y, Ferreccio C, Steinmaus C, Smith AH. Increased childhood liver cancer mortality and arsenic in drinking water in Northern Chile. Cancer Epidemiol Biomarkers Prev. 1998; 17:1982-1987. [PubMed: 18708388]

58. Lin S, Shi Q, Nix FB, Styblo M, Beck MA, Herbin-Davis KM, Hall LL, Simeonsson JB, Thomas DJ. A novel S-adenosyl-L-methionine:arsenic(III) methyltransferase from rat liver cytosol. J Biol Chem. 2002; 277:10795-10803. [PubMed: 11790780] 
59. Lin Y, Dueker SR, Follett JR, Fadel JG, Arjomand A, Schneider PD, Miller JW, Green R, Buchholz BA, Vogel JS, Phair RD, Clifford AJ. Quantitation of in vivo human folate metabolism. Am J Clin, Nutr. 2004; 80:680-691. [PubMed: 15321809]

60. Lindberg AL, Rahman M, Persson LA, Vahter M. The risk of arsenic induced skin lesions in Bangladesh men and women is affected by arsenic metabolism and the age at first exposure. Toxicol Appl Pharmacol. 2008; 230:9-16. [PubMed: 18336856]

61. Liu J, Xie Y, Cooper R, Ducharme DM, Tennant R, Diwan BA, Waalkes MP. Transplacental exposure to inorganic arsenic at a hepatocarcinogenic dose induces fetal gene expression changes in mice indicative of aberrant estrogen signaling and disrupted steroid metabolism. Toxicol Appl Pharmacol. 2007; 220:284-291. [PubMed: 17350061]

62. Livak KJ, Schmittgen TD. Analysis of relative gene expression data using real-time quantitative PCR and $2^{-\Delta \Delta C}$ T method. Methods. 2001; 25:402-408. [PubMed: 11846609]

63. Lorenz JM, Wooliever DE, Jetton JR, Paneth N. A quantitative review of mortality and developmental disability in extremely premature newborns. Arch Pediatr Adolesc Med. 1998; 152:425-435. [PubMed: 9605024]

64. Malinow MR, Nieto FJ, Kruger WD, Duell PB, Hess DL, Gluckman RA, Block PC, Holzgang CR, Anderson PH, Seltzer D, Upson B, Lin QR. The effects of folic acid supplementation on plasma total homocysteine are modulated by multivitamin use and metjhylentetrahydrofolate reductase genotypes. Arterioscler Thromb Vasc Biol. 1997; 17:1157-1162. [PubMed: 9194768]

65. Markowski VP, Reeve EA, Onos K, Assadollahzadeh M, McKay N. Effects of prenatal exposure to sodium arsenite on motor and food-motivated behaviors from birth to adulthood in C57BL6/J mice. Neurotoxicol Teratol. 2012; 34:221-231. [PubMed: 22266078]

66. Martinez L, Jimenez V, Garcia-Sepulveda C, Ceballos F, Delgado JM, Nino-Moreno P, Doniz L, Saavedra-Alanis V, Castillo CG, Santoyo ME, Gonzalez-Amaro R, Jimenez-Capdeville ME. Impact of early developmental arsenic exposure on promoter $\mathrm{CpG}$-island methylation of genes involved in neuronal plasticity. Neurochem Int. 2011; 58:574-581. [PubMed: 21300125]

67. McLaughlin CC, Babtiste MS, Schymura MJ, Nasca PC, Zdeb MS. Maternal and infant birth characteristics and hepatoblastoma. Am J Epidemiol. 2006; 163:818-828. [PubMed: 16510543]

68. McMinn J, Wei M, Schupf N, Cusmai J, Johnson EB, Smith AC, Weksberg R, Thaker HM, Tycko B. Unbalanced placental expression of imprinted genes in human intrauterine growth restriction. Placenta. 2006; 27:540-549. [PubMed: 16125225]

69. Navas-Acien A, Sharrett AR, Silbergeld EK, Silbergeld EK, Schwartz BS, Nachman KE, Burke TA, Guallar E. Arsenic exposure and cardiovascular disease: a systematic review of the epidemiologic evidence. Am J Epidemiol. 2005; 162:1037-1049. [PubMed: 16269585]

70. Navas-Acien A, Silbergeld EK, Pastor-Barriuso R, Guallar E. Arsenic exposure and prevalence of type 2 diabetes in US adults. JAMA. 2008; 300:814-822. [PubMed: 18714061]

71. Nelson GM, Ahlborn GJ, Delker DA, Kitchin KT, O’Brien TG, Chen Y, Kohan MJ, Roop BC, Ward WO, Allen JW. Folate deficiency enhances arsenic effects on expression of genes involved in epidermal differentiation in transgenic K6/ODC mouse skin. Toxicology. 2007; 241:134-145. [PubMed: 17928125]

72. Paul DS, Hernández-Zavala A, Walton FS, Adair BM, Dedina J, Matou ek T, Styblo M. Examination of the effects of arsenic on glucose homeostasis in cell culture and animal studies: development of a mouse model for arsenic-induced diabetes. Toxicol Appl Pharmacol. 2007; 222:305-314. [PubMed: 17336358]

73. Paul DS, Walton FS, Saunders RJ, Styblo M. Characterization of the impaired glucose homeostasis produced in C57BL/6 mice by chronic exposure to arsenic and high-fat diet. Environ Health Perspect. 2011; 119:1104-1109. [PubMed: 21592922]

74. Perera F, Herbstman J. Prenatal environmental exposures, epigenetics, and disease. Reprod Toxicol. 2011; 31:363-373. [PubMed: 21256208]

75. Pietrzik K, Lamers Y, Bramswig S, Prinz-Langenohl R. Calculation of red blood cell folate steady state conditions and elimination kinetics after daily supplementation with various forms and doses in women of childbearing age. Am J Clin Nutr. 2007; 86:1414-1419. [PubMed: 17991654]

76. Pilsner JR, Liu X, Ahsan H, Ilievski V, Slavkovitch V, Levy D, Factor-Litvak P, Graziano JH, Gamble MV. Folate deficiency, hyperhomocysteinemia, low urinary creatinine, and 
hypomethylation of leukocyte DNA are risk factors for arsenic-induced skin lesions. Environ Health Perspect. 2009; 117:254-260. [PubMed: 19270796]

77. Pilsner JR, Hall MN, Liu X, Ilievski V, Slavkovich V, Levy D, Factor-Litvak P, Yunus M, Rahman M, Graziano JH, Gamble MV. Influence of prenatal arsenic exposure and newborn sex on global methylation of cord blood DNA. PLoS ONE. 2012; 7:e37147. [PubMed: 22662134]

78. Rader JI. Folic acid fortification, folate status and plasma homocysteine. J Nutr. 2002; 132:2466S2470S. [PubMed: 12163713]

79. Resnick MB, Gueorquieva RV, Carter RL, Ariet M, Sun Y, Roth J, Bucciarelli RL, Curran JS, Mahan CS. The impact of low birth weight, perinatal conditions, and sociodemographic factors on educational outcome in kindergarten. Pediatrics. 1999; 104:e74. [PubMed: 10586008]

80. Revill K, Dudley KJ, Clayton RN, McNicol AM, Farrell WE. Loss of neuronatin expression is associated with promoter hypermethylation in pituitary adenoma. Endocr Relat Cancer. 2009; 16:537-548. [PubMed: 19218280]

81. Reynolds P, Urayama KY, Von Behren J, Feusner J. Birth characteristics and hepatoblastoma risk in young children. Cancer. 2004; 100:1070-1076. [PubMed: 14983504]

82. Rosado JL, Ronquillo D, Kordas K, Rojas O, Alatorre J, Lopez P, Garcia-Vargas G, Caamano MC, Cebrian ME, Stoltzfus R. Arsenic exposure and cognitive performance in Mexican schoolchildren. Environ Health Perspect. 2007; 155:1371-1375. [PubMed: 17805430]

83. Rudge CV, Rollin HB, Nogueira CM, Thomassen Y, Rudge MC, Odland JO. The placenta as a barrier for toxic and essential elements in paired maternal and cord blood samples of South African delivering vomen. J Environ Monit. 2009; 11:1322- 1330. [PubMed: 20449220]

84. Saeed AI, Sharov V, White J, Li J, Liang W, Bhagabati N, Braisted J, Klapa M, Currier T, Thiagarajan M, Sturn A, Snuffin M, Rezantsev A, Popov D, Ryltsov A, Kostukovich E, Borisovsky I, Liu Z, Vinsavich A, Trush V, Quackenbush J. TM4: a free, open-source system for microarray data management and analysis. Biotechniques. 2003; 34:374-378. [PubMed: 12613259]

85. Saigal S, Hoult LA, Streiner DL, Stoskopf BL, Rosenbaum PL. School difficulties at adolescence in a regional cohort of children who were extremely low birth weight. Pediatrics. 2000; 105:325331. [PubMed: 10654950]

86. Sharma S, De Carvalho DD, Jeong S, Jones PA, Liang G. Nucleosomes containing methylated DNA stabilize DNA methyltransferases 3A/3B and ensure faithful epigenetic inheritance. PLoS Genet. 2011; 7:e1001286. [PubMed: 21304883]

87. She QB, Nagao I, Hayakawa T, Tsuge H. A simple HPLC method for the determination of Sadenosylmethionine and $\mathrm{S}$-adenosylhomocysteine in rat tissues: The effect of vitamin B6 deficiency on these concentrations in rat liver. Biochem Biophys Res Commun. 1994; 205:17481754. [PubMed: 7811261]

88. Shen J, Liu J, Xie Y, Diwan BA, Waalkes MP. Fetal onset of aberrant gene expression relevant to pulmonary carcinogenesis in lung adenocarcinoma development induced by in utero arsenic exposure. Toxicol Sci. 2007; 95:313-320. [PubMed: 17077188]

89. Smeester L, Rager JE, Bailey KA, Guan X, Smith N, Garcia-Vargas G, Del Razo LM, Drobna Z, Kelkar H, Styblo M, Fry RC. Epigenetic changes in individuals with arsenicosis. Chem Res Toxicol. 2011; 24:165-167. [PubMed: 21291286]

90. Smith AH, Lingas EO, Rahman M. Contamination of drinking-water by arsenic in Bangladesh: a public health emergency. Bulletin of World Health Organization. 2000; 78:1093-1103.

91. Spector LG, Johnson KJ, Puumala SE. Perinatal risk factors for hepatoblastoma. Br J Cancer. 2008; 98:1570-1573. [PubMed: 18392049]

92. Spector LG, Puumala SE, Carozza SE, Chow EJ, Fox EE, Horel S, Johnson KJ, McLaughlin CC, Reynolds P, Von Behren J, Mueller BA. Cancer risk among children with very low birth weights. Pediatrics. 2009; 124:96-104. [PubMed: 19564288]

93. States JC, Srivastava S, Chen Y, Barchowsky A. Review: Arsenic and cardiovascular disease. Tox Science. 2009; 107:312-323.

94. Styblo M, Drobna Z, Jaspers I, Lin S, Thomas DJ. The role of biomethylation in toxicity and carcinogenicity of arsenic: a research update. Environ Health Perspect. 2002; 110:767-771. [PubMed: 12426129] 
95. Tabano S, Colapietro P, Cetin I, Grati FR, Zanutto S, Mando C, Antonazzo P, Pileri P, Rossella F, Larizza L, Sirchia SM, Miozzo M. Epigenetic modulation of the IGF2/H19 imprinted domain in human embryonic and extra-embryonic compartments and its possible role in fetal growth restriction. Epigenetics. 2010; 5:313-324. [PubMed: 20418667]

96. Takeshita K, Suetake I, Yamashita E, Suga M, Narita H, Nakagawa A, Tajima S. Structural inside into maintenance methylation by mouse DNA methylatransferase 1 (Dnmt1). Proc Natl Acad Sci USA. 2011; 108:9055-9059. [PubMed: 21518897]

97. Tamura, T. Microbiological assay of folates. In: Piccaino, MF.; Stokstad, ELR.; Gregory, JF., editors. Folic Acid Metabolism in Health and Disease. New York: Willey-Liss; 1990. p. 121-137.

98. Tanimura M, Matsui I, Abe J, Ikeda H, Kobayashi N, Ohira M, Yokoyama M, Kaneko M. Increased risk of hepatoblastoma among immature children with a lower birth weight. Cancer Res. 1998; 58:3032-3035. [PubMed: 9679968]

99. The World Health Organization (WHO). Guidelines for drinking-water quality. 4. WHO; Geneva, Switzerland: 2011. p. 1-541.http://whqlibdoc.who.int/publications/2011/9789241548151_eng.pdf

100. Tokar EJ, Diwan BA, Thomas DJ, Waalkes MP. Tumors and proliferative lesions in adult offspring after maternal exposure to methylarsonous acid during gestation in CD1 mice. Arch Toxicol. 2012; 86:975-982. [PubMed: 22398986]

101. Tsai SY, Chou HY, The HW, Chen CM, Chen CJ. The effects of chronic arsenic exposure on the neurobehavioral development in adolescence. Neurotoxicology. 2003; 24:747-753. [PubMed: 12900089]

102. Tusher VG, Tibshirani R, Chu G. Significance analysis of microarrays applied to the ionizing radiation response. Proc Natl Acad Sci U S A. 2001; 98:5116-5121. [PubMed: 11309499]

103. Vahter M, Concha G, Nermell B, Nilsson R, Dulout F, Natarajan AT. A unique metabolism of inorganic arsenic in native Andean women. Eur J Pharmacol. 1995; 293:455-462. [PubMed: 8748699]

104. Vahter M, Akesson A, Liden C, Ceccatelli S, Berglund M. Gender differences in the disposition and toxicity of metals. Environ Res. 2007; 104:85-95. [PubMed: 16996054]

105. Vahter M. Health effects of early life exposure to arsenic. Basic Clin Pharmacol Toxicol. 2008; 102:204-211. [PubMed: 18226075]

106. Valenzuela OL, Borja-Aburto VH, Garcia-Vargas GG, Cruz-Gonzalez MB, Garcia-Montalvo EA, Calderon-Aranda ES, Del Razo LM. Urinary trivalent methylated arsenic species in a population chronically exposed to inorganic arsenic. Environ Health Perspect. 2005; 113:250-254.

[PubMed: 15743710]

107. Valenzuela O, Drobna Z, Hernandez-Castellanos E, Sanchez-Pena LC, Garcia-Vargas GG, BorjaAburto VH, Styblo M, Del Razo LM. Association of AS3MT polymorphisms and the risk of premalignant arsenic skin lesions. Tox Appl Pharmacol. 2009; 239:200-207.

108. Von Ehrenstein OS, Mazumder DNG, Smith MH, Ghosh N, Yuan Y, Windham G, Ghosh A, Haque R, Lahiri S, Kalman D, Das S, Smith AH. Pregnancy outcomes, infant mortality, and arsenic in drinking water in West Bengal, India. Am J Epidemiol. 2005; 163:662-669. [PubMed: 16524957]

109. Waalkes MP, Ward JM, Liu J, Diwan BA. Transplacental carcinogenicity of inorganic arsenic in the drinking water: induction of hepatic, ovarian, pulmonary, and adrenal tumors in mice. Toxicol Appl Pharmacol. 2003; 186:7-17. [PubMed: 12583988]

110. Waalkes MP, Liu J, Chen H, Xie Y, Achanzar WE, Zhou YS, Cheng ML, Diwan BA. Estrogen signaling in livers of male mice with hepatocellular carcinoma induced by exposure to arsenic in utero. J Natl Cancer Inst. 2004; 96:466-474. [PubMed: 15026472]

111. Waalkes MP, Liu J, Ward JM, Powel DA, Diwan BA. Urogenital carcinogenesis in female CD1 mice induced by in utero arsenic exposure is exacerbated by postnatal diethylstilbestrol treatment. Cancer Res. 2006a; 66:1337-1345. [PubMed: 16452187]

112. Waalkes MP, Liu J, Ward JM, Diwan BA. Enhanced urinary bladder and liver carcinogenesis in male CD1 mice exposed to transplacental inorganic arsenic and postnatal diethylstilbestrol ortamoxifen. Toxicol Appl Pharmacol. 2006b; 215:295-305. [PubMed: 16712894]

113. Waalkes MP, Liu J, Diwan BA. Transplacental arsenic carcinogenesis in mice. Toxicol Appl Pharmacol. 2007; 222:271-280. [PubMed: 17306315] 
114. Wasserman GA, Liu X, Parvez F, Ahsan H, Factor-Litvak P, Kline J, van Geen A, Slavkovich V, Loiacono NJ, Levy D, Cheng Z, Graziano JH. Water arsenic and intellectual function in 6-yearold children in Araihazar, Bangladesh. Environ Health Perspect. 2007; 115:285-289. [PubMed: 17384779]

115. Waters SB, Devesa V, Del Razo LM, Styblo M, Thomas DJ. Endogenous reductants support the catalytic function of recombinant rat cyt19, an arsenic methyltransferase. 2004

116. Whittaker S, Marais R, Zhu AX. The role of signaling pathways in the development and treatment of hepatocellular carcinoma. Oncogene. 2010; 29:4989-5005. [PubMed: 20639898]

117. Wijnholds J, Chowdhury K, Wehr R, Gruss P. Segment-specific expression of the neuronatin gene during early hindbrain development. Develop Biol. 1995; 171:73-84. [PubMed: 7556909]

118. Wlodarczyk BJ, Spiegelstein O, Gelineau-van Waes J, Vorce RL, Lu X, Le CX, Finnell RH. Arsenic-induced congenital malformations in genetically susceptible folate binding protein-2 knockout mice. Toxicol Appl Pharmacol. 2001; 177:238-246. [PubMed: 11749123]

119. Yan PS, Efferth T, Chen HL, Lin J, Rödel F, Fuzesi L, Huang THM. Use of CpG island microarrays to identify colorectal tumors with a high degree of concurrent methylation. Methods. 2002; 27:162-169. [PubMed: 12095276]

120. Yang CY, Chang CC, Tsai SS, Chuang HY, Ho CK, Wu TN. Arsenic in drinking water and adverse pregnancy outcome in an arseniasis-endemic area in northeastern Taiwan. Environ Res. 2003; 91:29-34. [PubMed: 12550085]

121. Yevtodiyenko A, Schmidt JV. Dlk1 expression marks developing endothelium and sites of branching morphogenesis in the mouse embryo and placenta. Dev Dyn. 2006; 235:1115-1123. [PubMed: 16456855]

122. Zeisel SH. Importance of methyl donors during reproduction. Am J Clin Nutr. 2009; 89:673S677S. [PubMed: 19116320] 


\section{Research highlights}

- We used transplacental CD1 mice model for inorganic arsenic (iAs) carcinogenesis.

- We examined the effects of gestational iAs and high folate exposure on DNA methylation.

- iAs-folate interaction resulted in low fetal weights and changes in DNA methylation.

- Epigenetically altered genes were associated with cancer and neurodevelopment.

- We showed that in utero iAs-folate interaction negatively affects fetal development. 
Figure 1A.

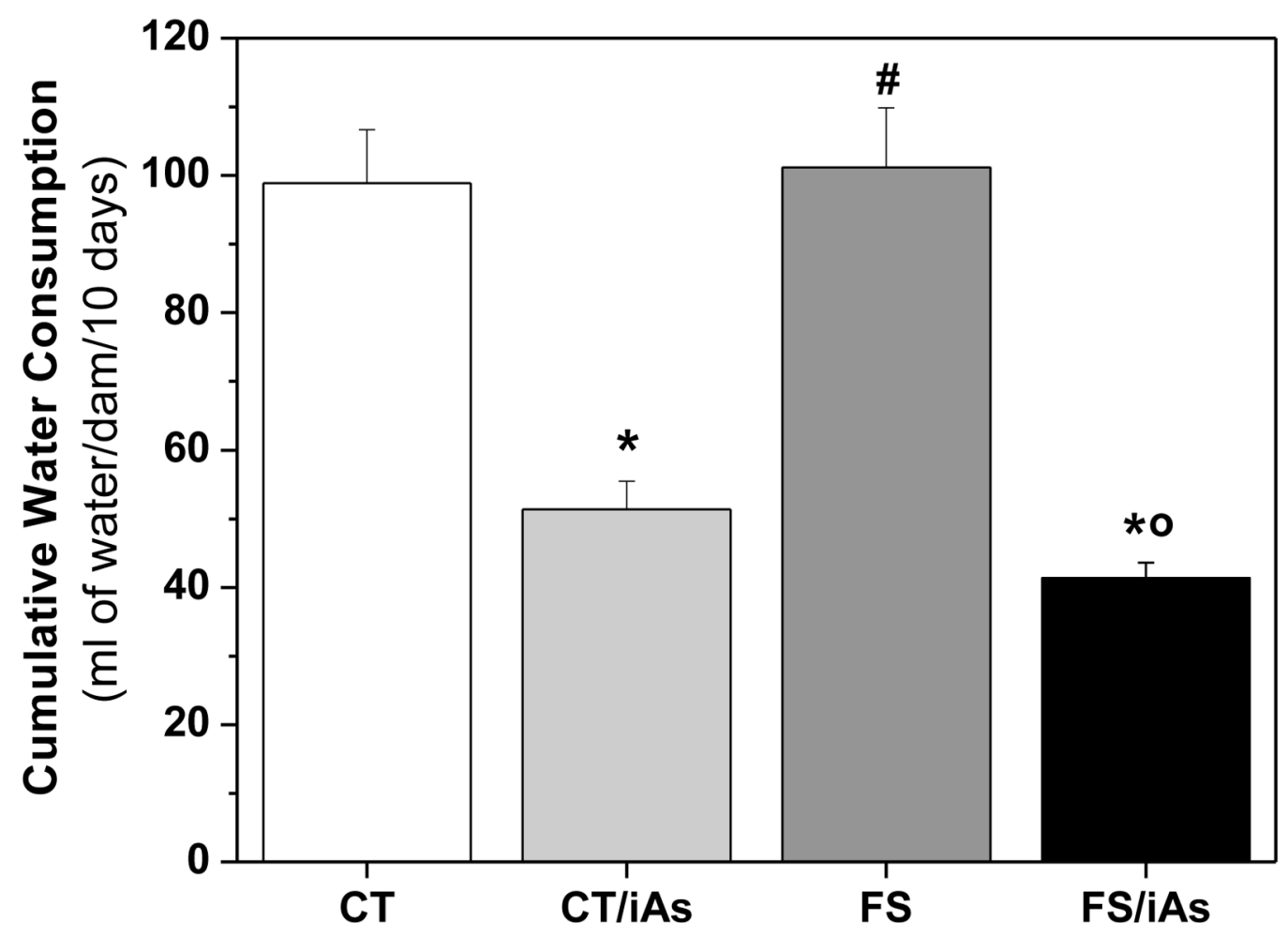

Figure 1B.

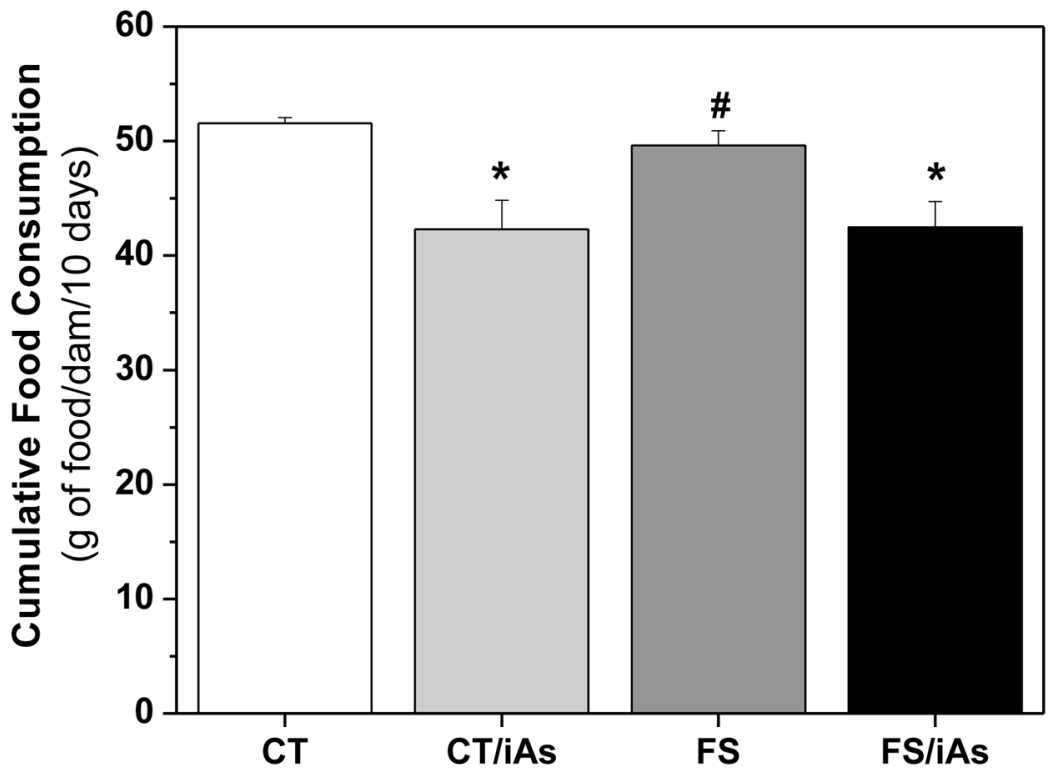


Figure 1C.

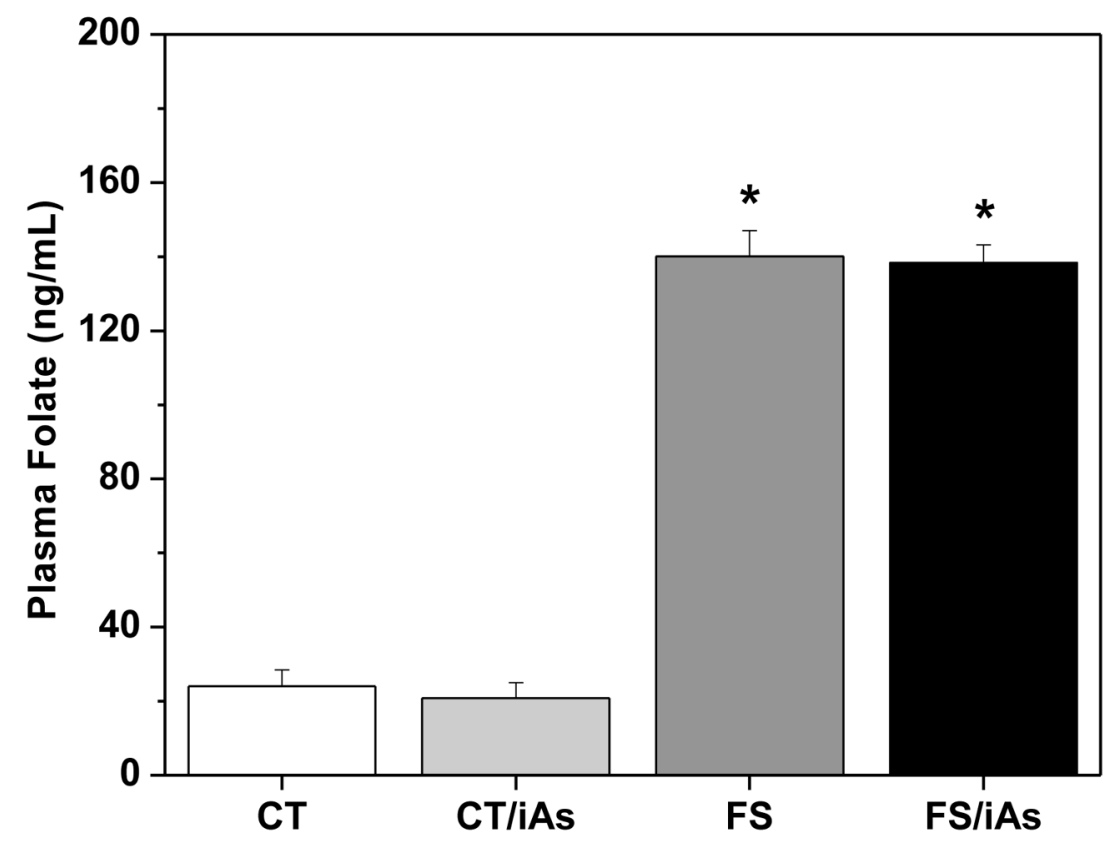

Figure 1D.

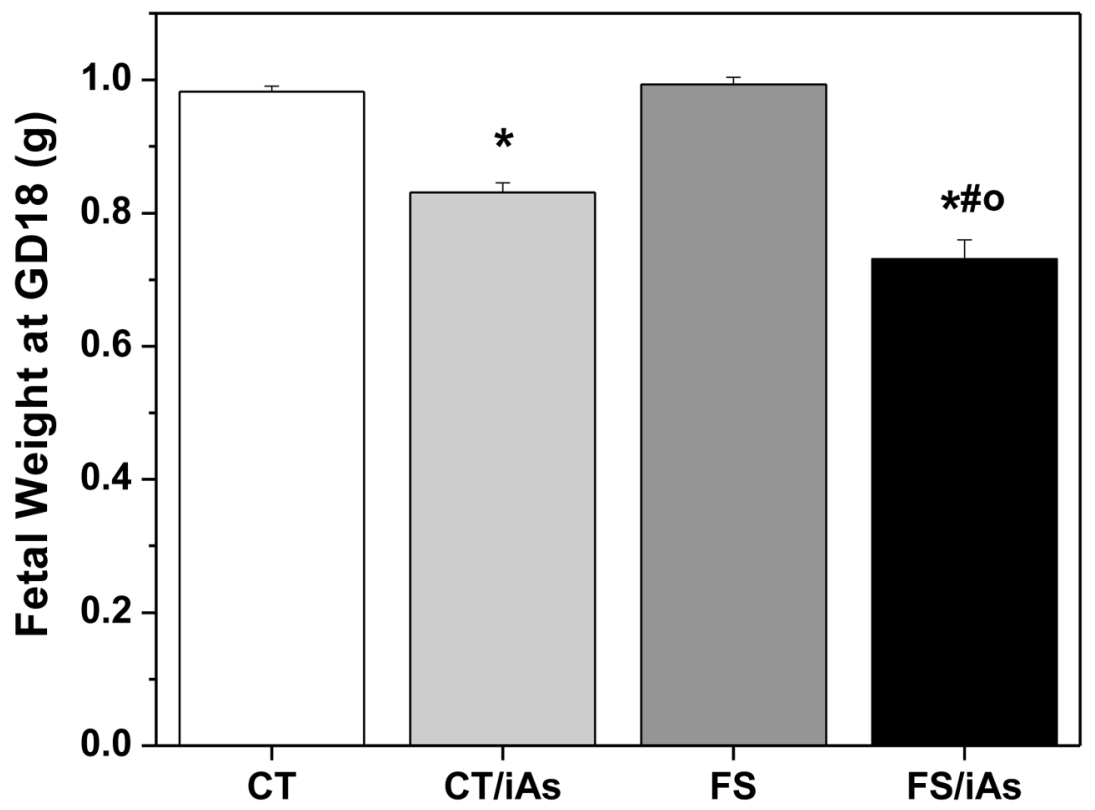

Fig. 1. Consumption of water (A), food (B), maternal plasma folate level (C), and average fetal weight (males and females) (D) at gestational day 18

Mean \pm SE; the number $(n)$ of dams $n=7-11$ for $A, B$, and $C$; the number $(n)$ of fetuses $N$ $=135-101$ for D. $*$, \#, o Denotes values that are significantly different from ${ }^{*} \mathrm{CT},{ }^{*} \mathrm{CT} /$ iAs, ${ }^{\circ} \mathrm{FS}$ at $\mathrm{p}<0.05$. 
Figure 2A.

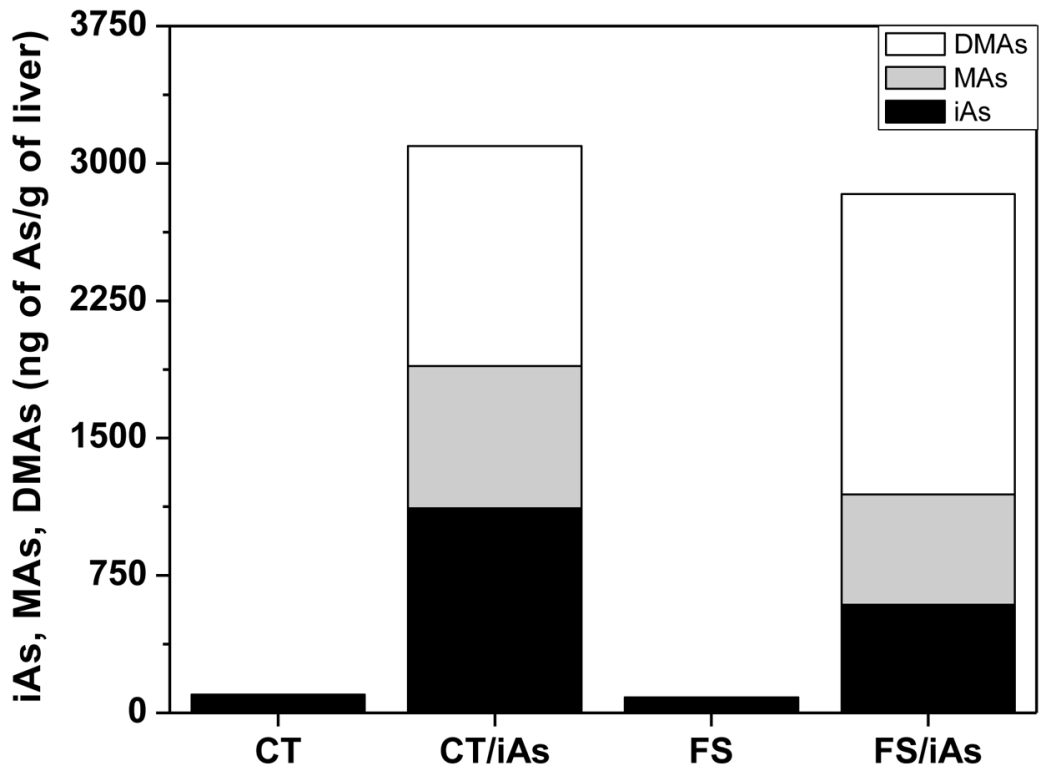

Figure 2B.

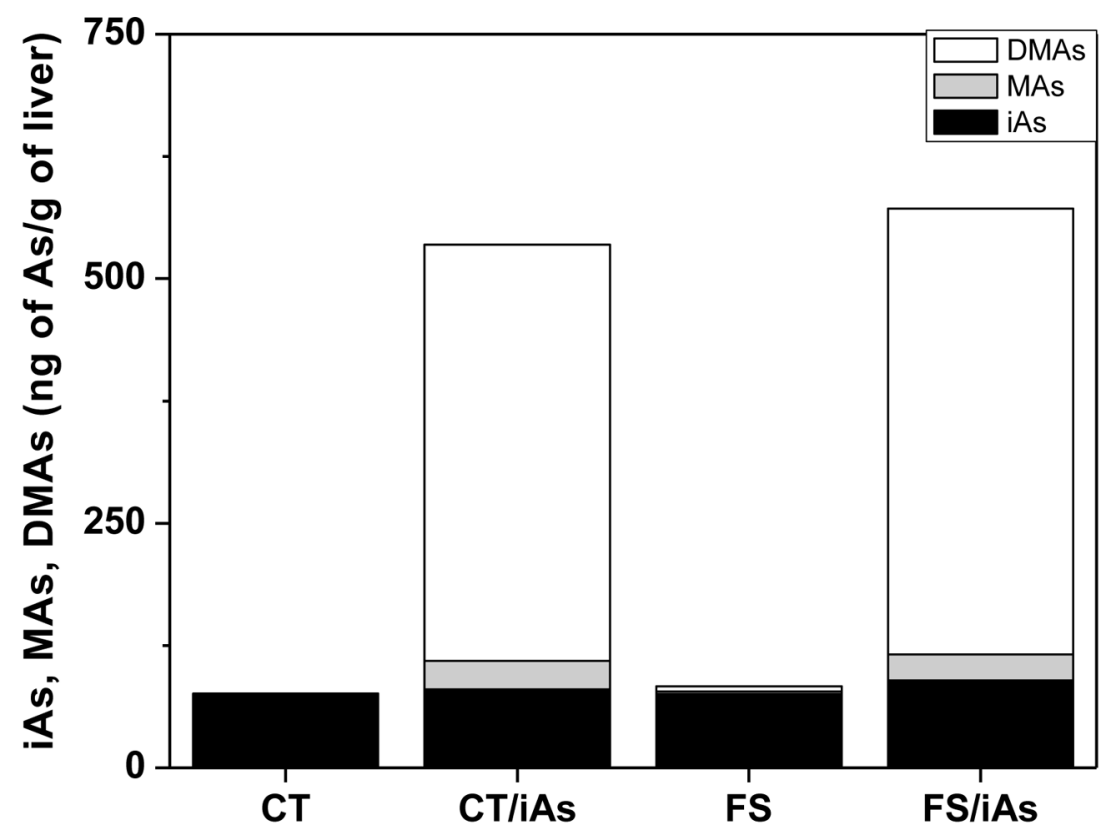


Figure 2C.

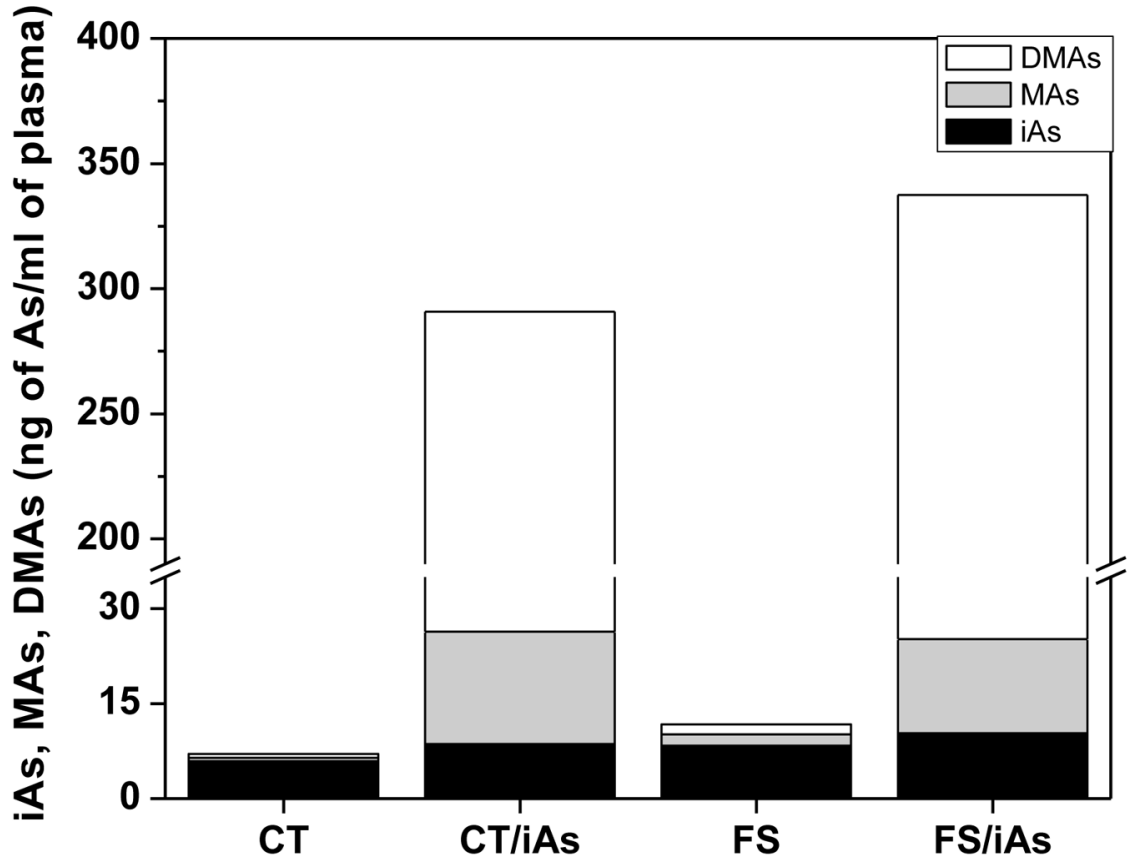

Fig. 2. Arsenic species in maternal (A) and fetal (B) livers and in maternal plasma (C) at gestational day 18

Mean values are shown for 7-11 dams and 7-10 fetuses. 
Figure 3A.

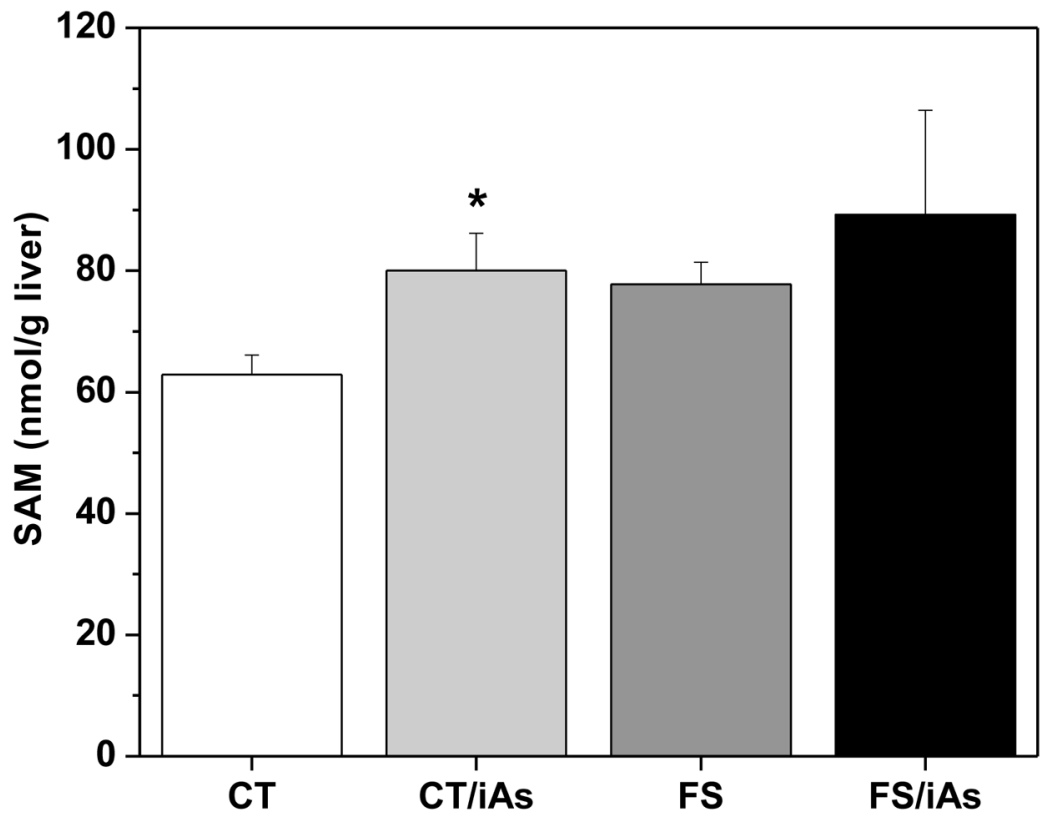

Figure 3B.

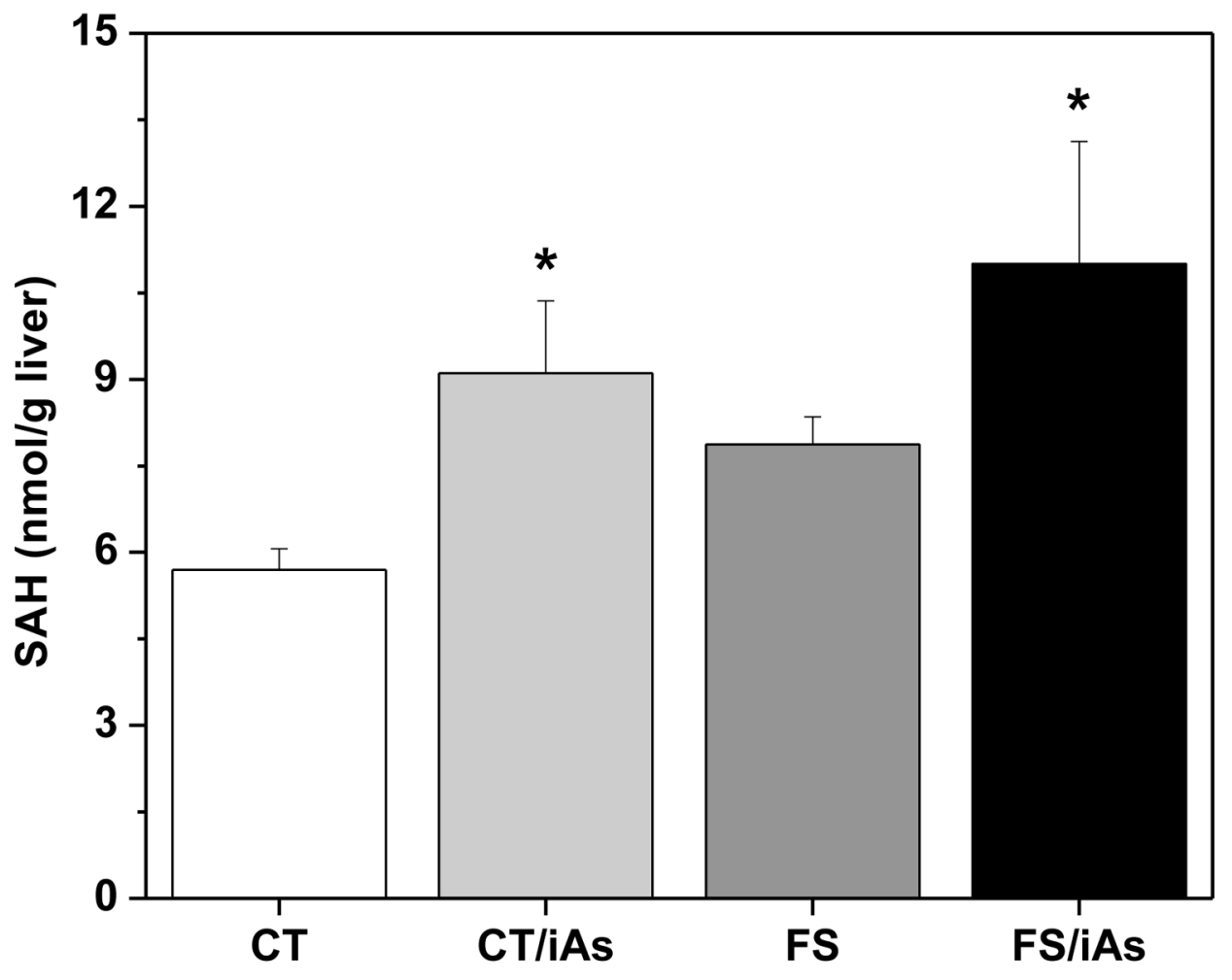


Figure 3C.

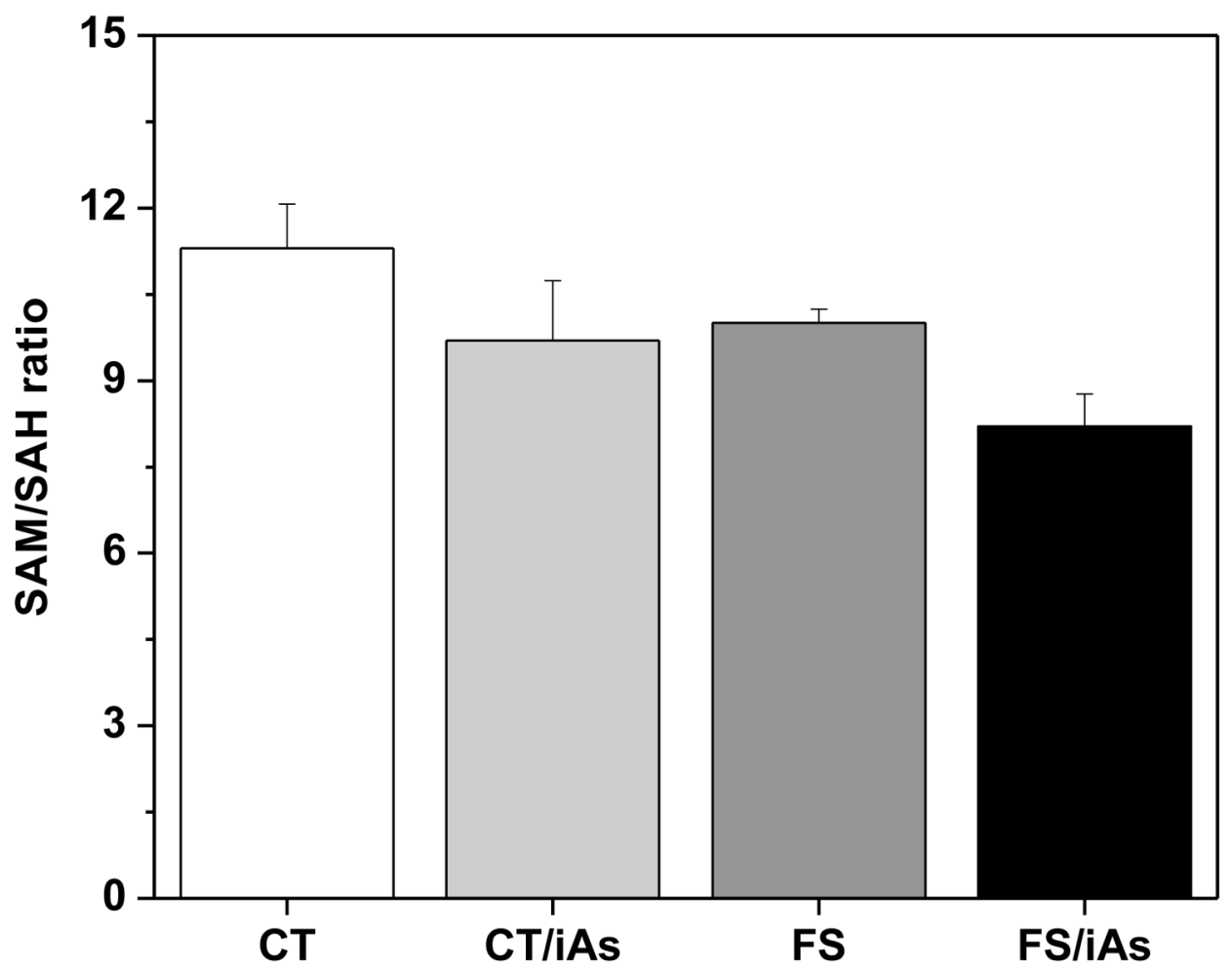

Fig. 3. SAM (A) and SAH (B) concentrations and SAM/SAH ratio (C) in fetal livers at gestational day 18

Mean \pm SE values are shown for 8-11 fetuses per treatment group. * Denotes significantly different from $* \mathrm{CT}$ at $\mathrm{p}<0.05$. 
Figure 4A.

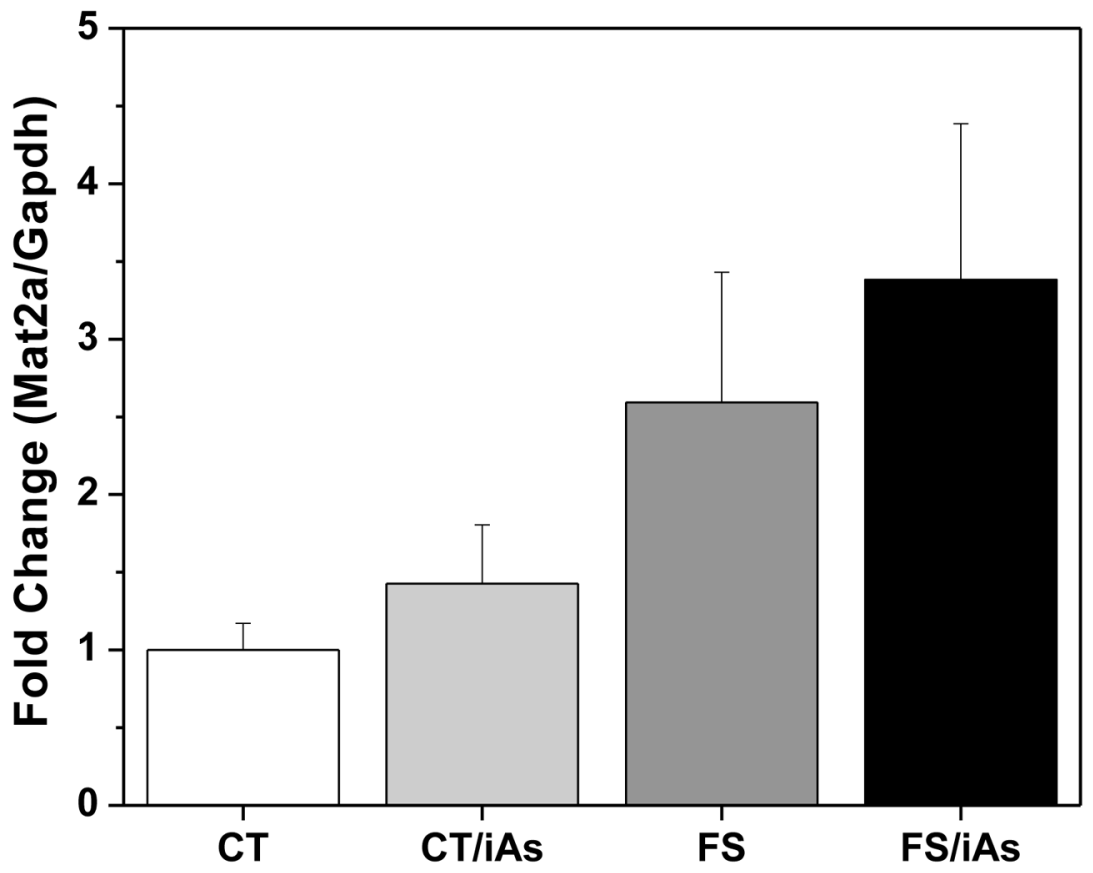

Figure 4B.

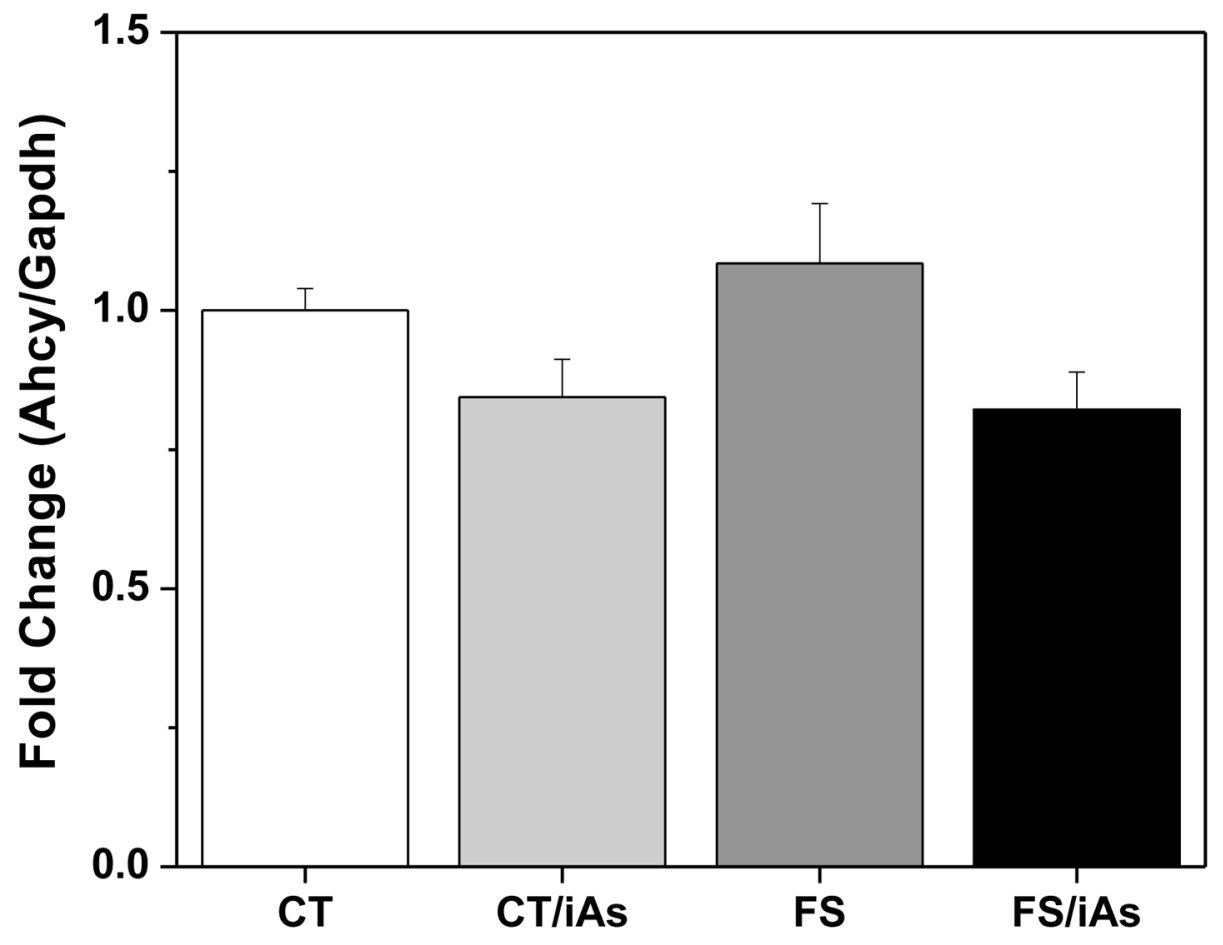


Figure 4C.

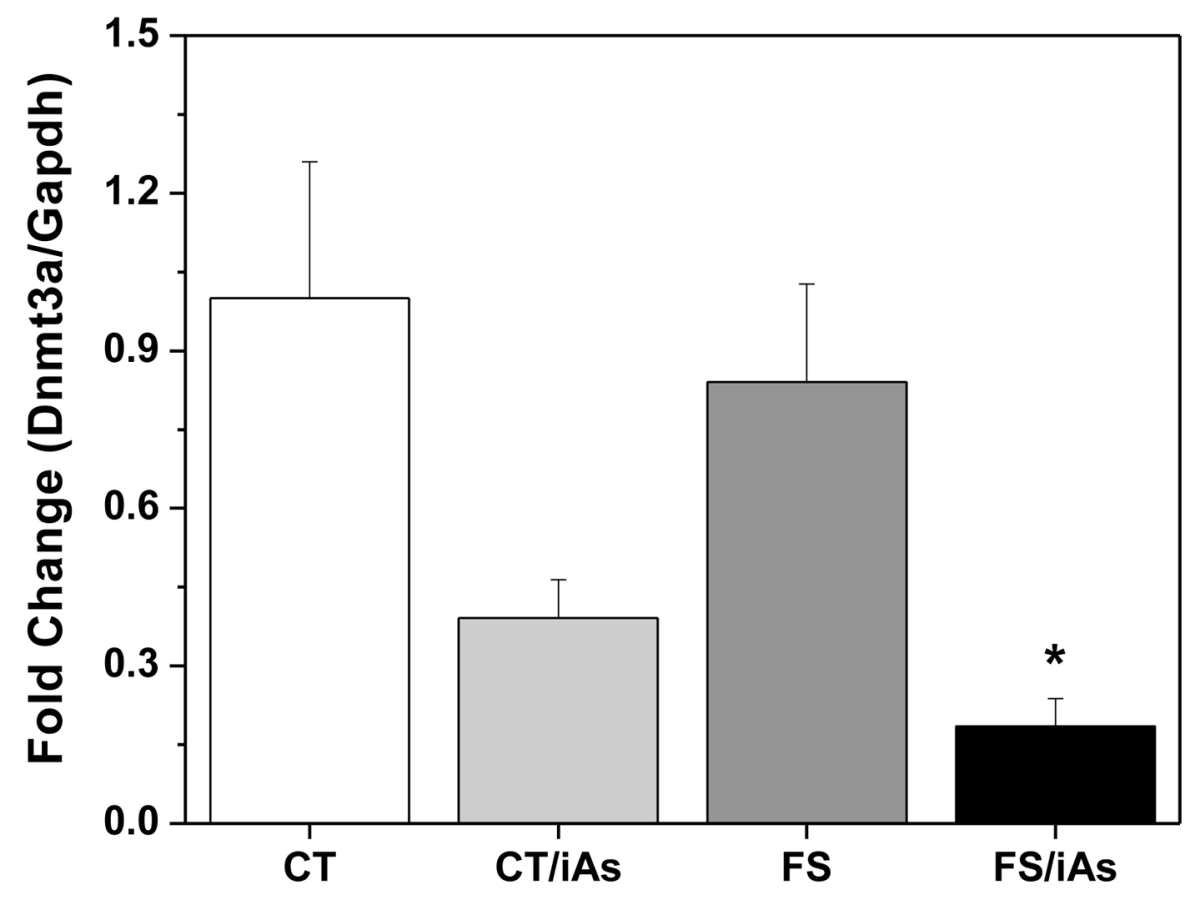

Fig. 4. Relative expression (mRNA) levels for (A), Ahcy (B) and Dnmt3a (C) in fetal livers at gestational day 18

Mean \pm SE values are shown for 7 fetuses per treatment group. * Denotes significantly different from $*$ CT at $\mathrm{p}<0.05$. 
FS vs. CT FS/iAs vs. CT

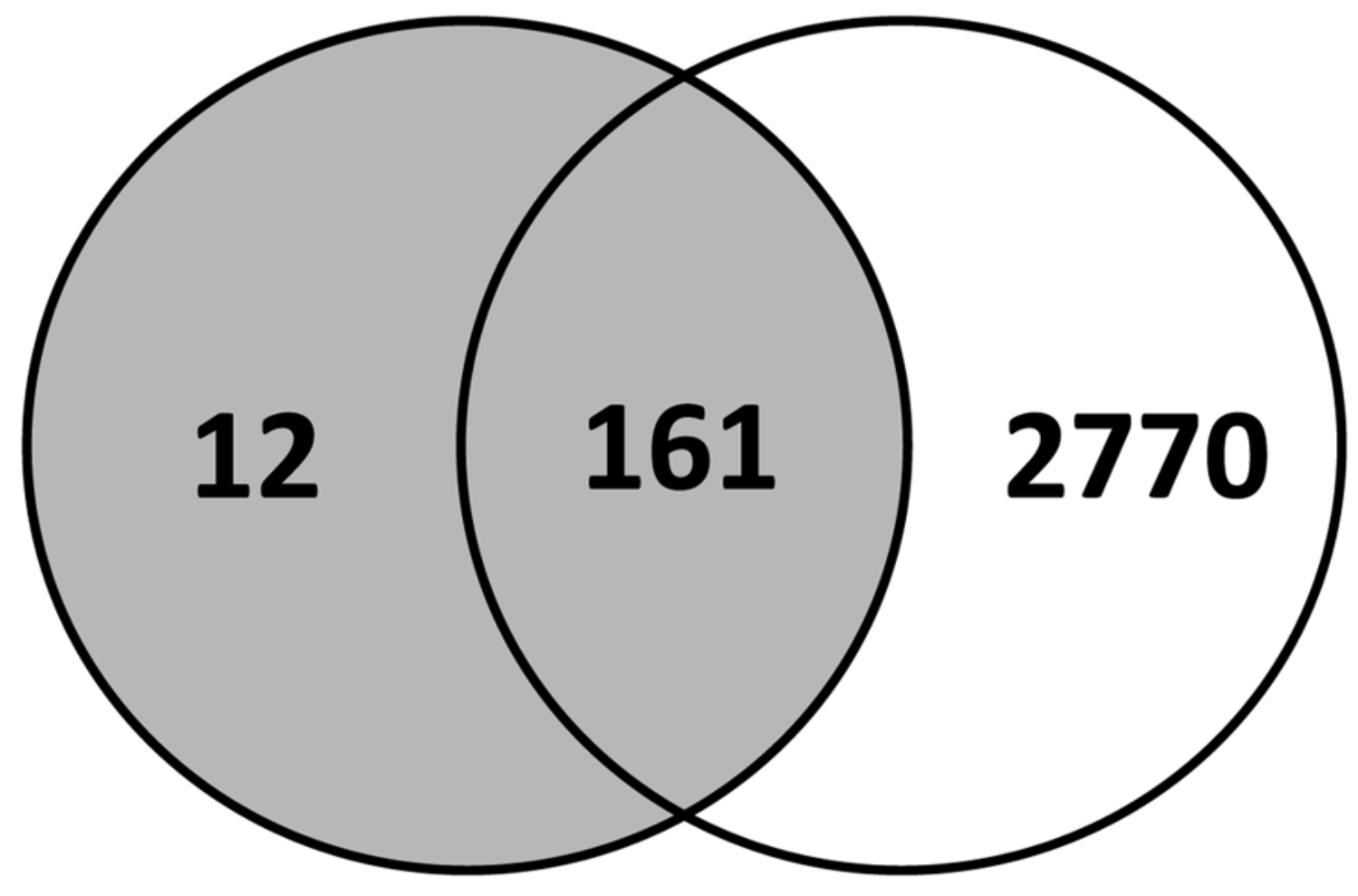

Fig. 5.

Venn diagram depicting the number of genes with significantly altered methylation profiles in fetal livers from FS and FS/iAs groups as compared to the control group (CT). 
Figure 6A.

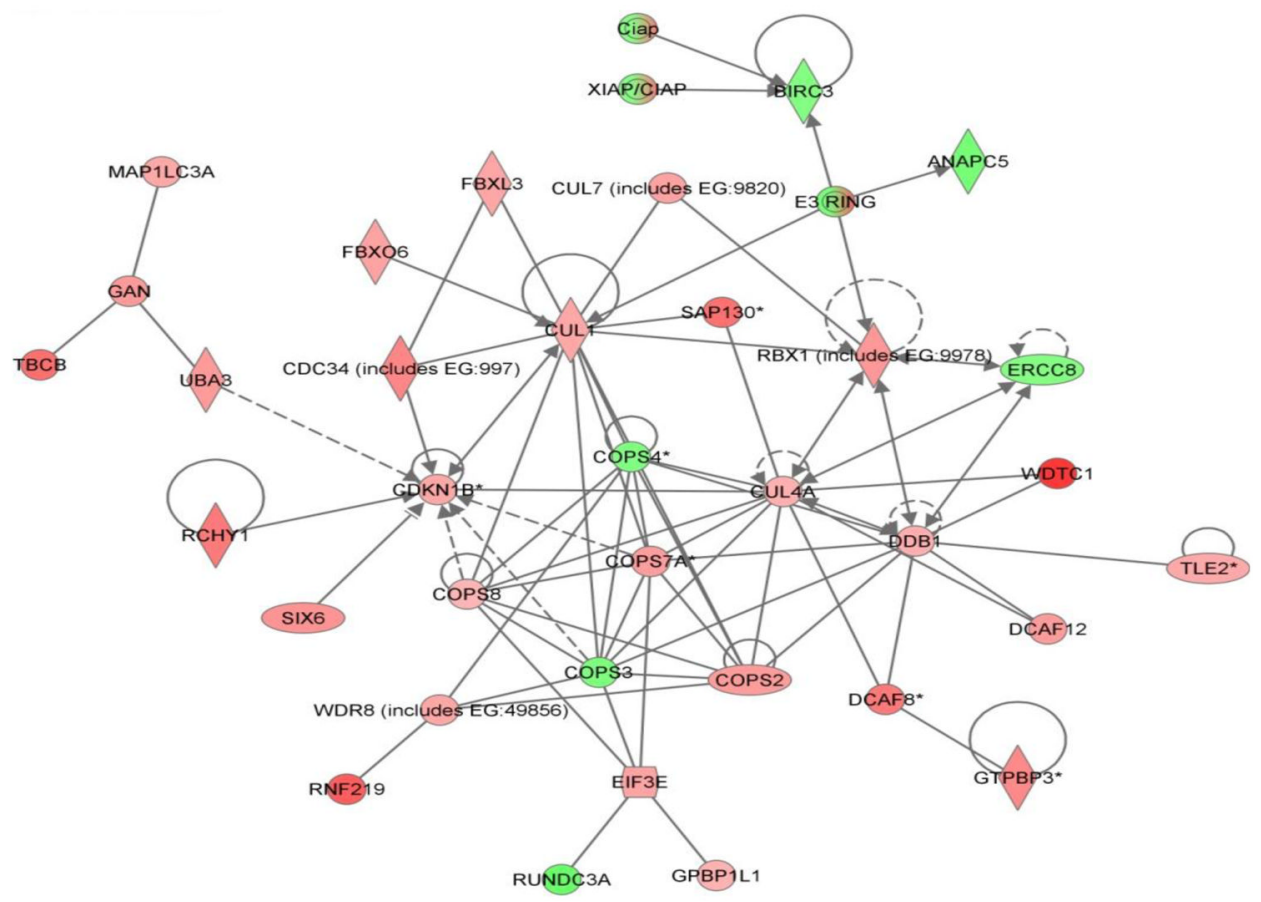

Figure 6B.

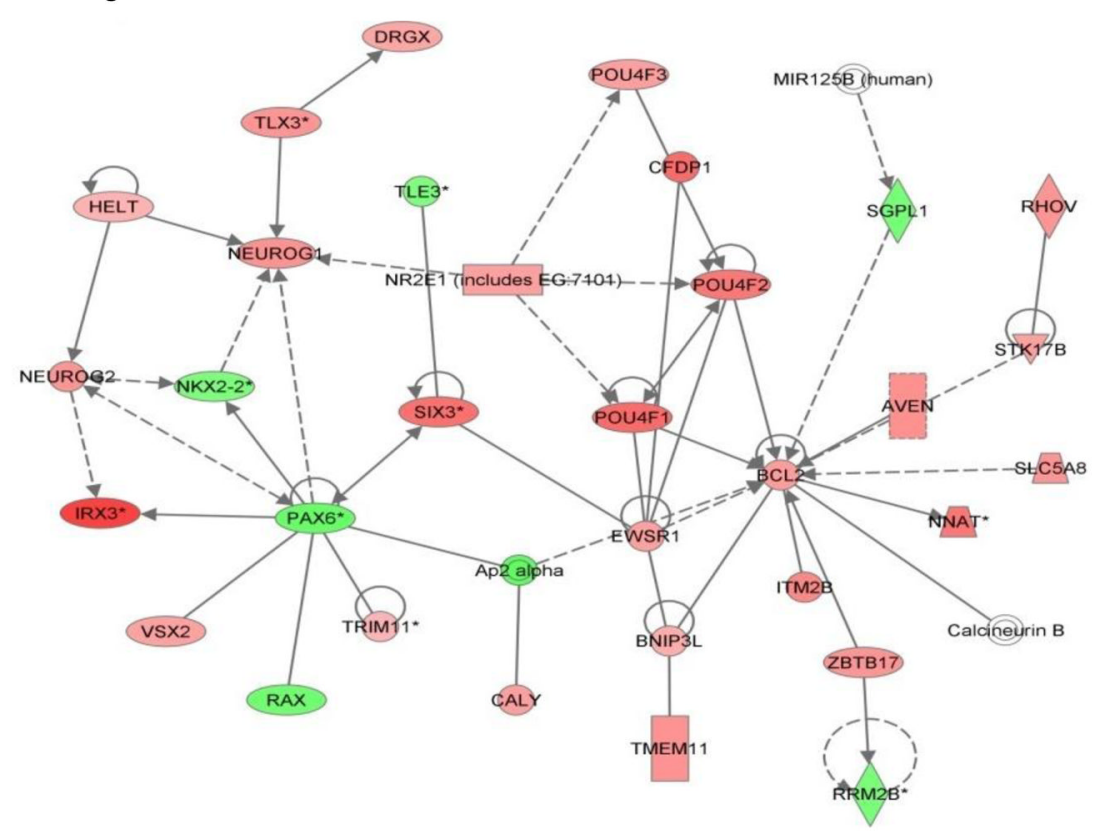

Fig. 6.

The cancer-associated (A) and neurological development and function-associated (B) molecular networks enriched for hypermethylated genes (in red) and hypomethylated genes (in green) in FS/iAs treatment group. 

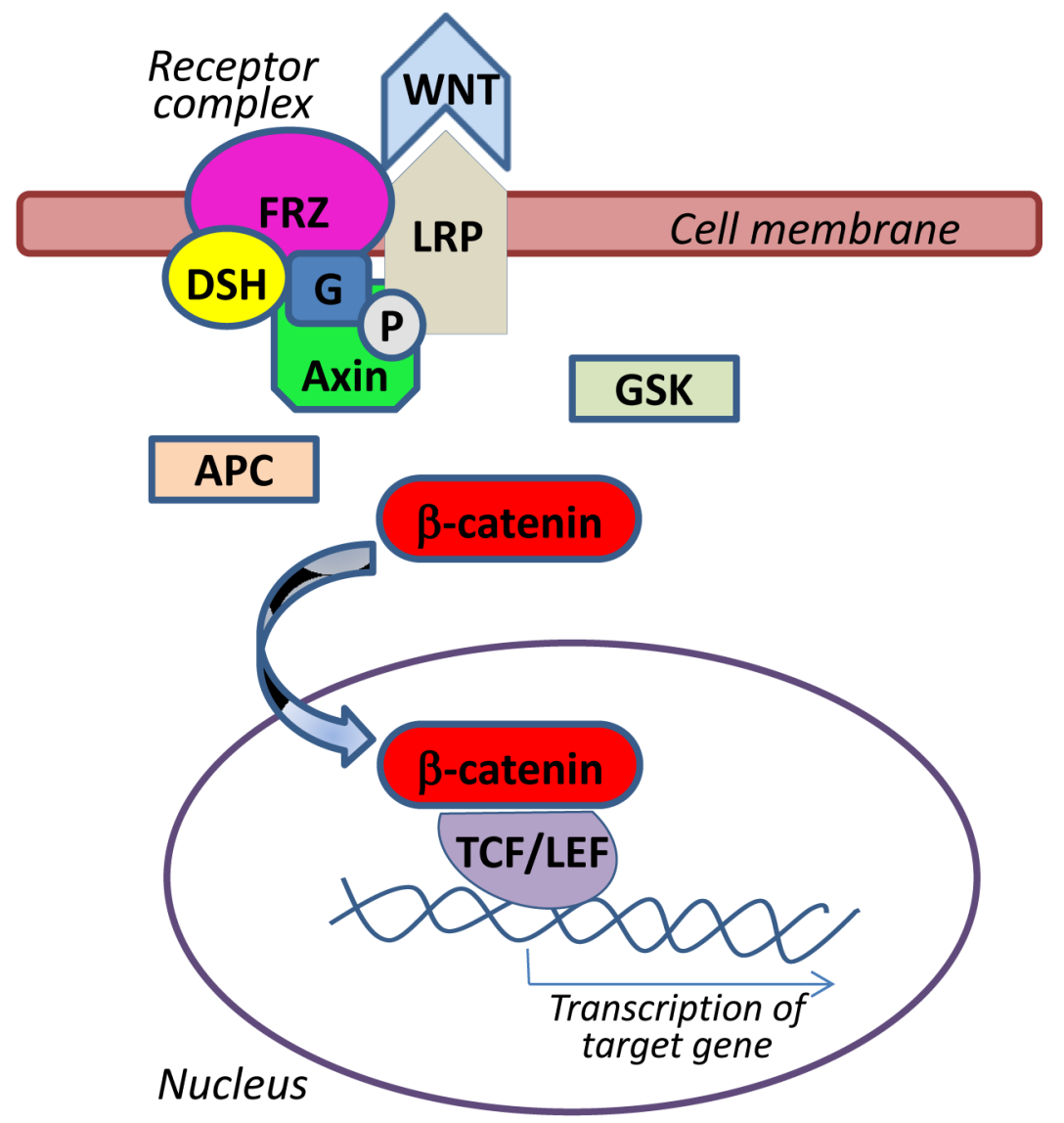

Fig. 7. The canonical Wnt pathway

WNT - WNT ligand; FRZ - Frizzled receptor; LRP - co-receptor; DSH - Dishevelled receptor complex protein; Axin/GSK/APC - complex promoting degradation of $\beta$-catenin; $\beta$-catenin - transcriptional co-activator; TCF/LEF - transcription factors. 


\section{Table 1}

Methylation ratios in CT/iAs and FS/iAs maternal livers.

\begin{tabular}{lccc}
\hline & MAs/iAs & DMAs/MAs & MAs+DMAs/iAs \\
\hline CT/iAs & & & \\
Average & 0.71 & 1.60 & 1.87 \\
SE & 0.04 & 0.21 & 0.21 \\
\hline FS/iAs & & & \\
Average & 1.16 & 3.22 & 4.29 \\
SE & 0.31 & 0.62 & 0.75 \\
\hline p-value & 0.08 & $\mathbf{0 . 0 1 *}$ & $\mathbf{0 . 0 0 2 *}$ \\
\hline
\end{tabular}




\section{Table 2}

Genes involved in Wnt-signaling pathway and significantly hypomethylated (green) or hypermethylated (red) in the liver of fetuses after high folate intake (FS) and combined high folate intake with in utero exposure to iAs (FS/iAs) as compared to the control (CT).

\begin{tabular}{|c|c|c|c|}
\hline Wnt pathway & Molecule & D-score (FS) & D-score (FS/iAs) \\
\hline \multirow[t]{11}{*}{ Wnt ligands } & Wnt1 & NA & 3.69 \\
\hline & $W n t 2 b$ & NA & -3.82 \\
\hline & Wnt3 & NA & -3.81 \\
\hline & Wnt3a & 5.74 & 5.60 \\
\hline & Wnt4 & NA & -5.84 \\
\hline & Wnt6 & NA & 8.54 \\
\hline & Wnt7a & NA & 5.27 \\
\hline & $W n t 7 b$ & NA & 3.25 \\
\hline & $W n t 9 b$ & NA & 4.71 \\
\hline & Wnt10a & NA & 7.77 \\
\hline & Wnt11 & NA & 3.50 \\
\hline \multirow[t]{2}{*}{ Dishevelled } & Dvl1 & NA & -5.25 \\
\hline & Dvl3 & NA & 3.45 \\
\hline Axin & Axin2 & NA & 3.15 \\
\hline$B$-catenin & Ctnnb1 & NA & 3.67 \\
\hline \multirow[t]{4}{*}{ Frizzled } & $F z d 5$ & NA & 4.49 \\
\hline & Fzd7 & NA & -4.15 \\
\hline & $F z d 8$ & NA & -5.00 \\
\hline & Fzd10 & NA & 3.91 \\
\hline$T c f / L e f$ & Tcf12 & NA & 3.22 \\
\hline
\end{tabular}

Note: D-score - Significance Analysis of Microarrays t-statistic value representing hypermethylated genes "+" and hypomethylated gene "-" as compared to control group; NA - gene not detected as significantly changed; FS - group of animals on high folate diet; FS/iAs - group of animals on high folate diet and receiving water containing arsenic. 
Table 3

Imprinted genes significantly hypomethylated (green) or hypermethylated (red) in livers of fetuses after high folate intake (FS) and combined high folate intake and in utero exposure to iAs (FS/iAs).

\begin{tabular}{lcccl}
\hline Gene & D-score (FS) & D-score (FS/iAs) & Expressed Allele & Protein Description \\
\hline Igf2r & 6.47 & 5.34 & Maternal & Insulin-like growth factor receptor 2 \\
\hline Grb10 & NA & 3.76 & Maternal (Isoform Dependent) & Growth factor receptor-bound protein 10; binds to igf2r \\
\hline Tssc4 & NA & -4.45 & Maternal & Tumor-suppressing candidate \\
\hline Dlk1 & NA & -3.77 & Paternal & Tumor-suppressing candidate \\
\hline Mest & -4.91 & -3.86 & Paternal & $\begin{array}{l}\text { Member of alpha/beta hydrolase family; cancer and } \\
\text { development }\end{array}$ \\
\hline Gnas & NA & 4.33 & Maternal (Isoform Dependent) & Neuroendocrine secretory protein 55 \\
\hline Nnat & NA & 6.08 & Paternal & Neuronatin; brain development \\
\hline Kcnk9 & -4.40 & -3.75 & Maternal & Potassium channel; highly expressed in brain \\
\hline
\end{tabular}

Note: D-score - Significance Analysis of Microarrays t-statistic value representing hypermethylated genes "+" and hypomethylated gene "-" as compared to control group (CT); NA - gene not detected as significantly changed; FS - mice on high folate diet; FS/iAs - mice on high folate diet receiving water containing arsenic. 